\title{
Cell type-specific Nogo-A gene ablation promotes axonal regeneration in the injured adult optic nerve
}

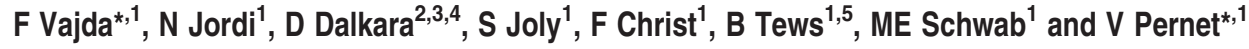

Nogo-A is a well-known myelin-enriched inhibitory protein for axonal growth and regeneration in the central nervous system (CNS). Besides oligodendrocytes, our previous data revealed that Nogo-A is also expressed in subpopulations of neurons including retinal ganglion cells, in which it can have a positive role in the neuronal growth response after injury, through an unclear mechanism. In the present study, we analyzed the opposite roles of glial versus neuronal Nogo-A in the injured visual system. To this aim, we created oligodendrocyte (Cnp-Cre ${ }^{+I-} \times R \operatorname{tn} 4 /$ Nogo- $A^{\text {flox/flox }}$ ) and neuron-specific (Thy1-Cre ${ }^{\text {tg }+}$ $x R \operatorname{tn} 4^{f l o x / f l o x}$ ) conditional Nogo-A knock-out (KO) mouse lines. Following complete intraorbital optic nerve crush, both spontaneous and inflammation-mediated axonal outgrowth was increased in the optic nerves of the glia-specific Nogo-A KO mice. In contrast, neuron-specific deletion of Nogo-A in a KO mouse line or after acute gene recombination in retinal ganglion cells mediated by adeno-associated virus serotype 2 .Cre virus injection in Rtn $4^{\text {flox/flox }}$ animals decreased axon sprouting in the injured optic nerve. These results therefore show that selective ablation of Nogo-A in oligodendrocytes and myelin in the optic nerve is more effective at enhancing regrowth of injured axons than what has previously been observed in conventional, complete Nogo-A KO mice. Our data also suggest that neuronal Nogo-A in retinal ganglion cells could participate in enhancing axonal sprouting, possibly by cis-interaction with Nogo receptors at the cell membrane that may counteract trans-Nogo-A signaling. We propose that inactivating Nogo-A in glia while preserving neuronal Nogo-A expression may be a successful strategy to promote axonal regeneration in the CNS.

Cell Death and Differentiation (2015) 22, 323-335; doi:10.1038/cdd.2014.147; published online 26 September 2014

In the adult mammalian central nervous system (CNS), axons have a very limited capacity to regenerate after traumatic injury. This lack of axonal regeneration is thought to be mainly due to the presence of growth-inhibiting molecules in the injured CNS environment ${ }^{1,2}$ and due to the low intrinsic growth capacity of mature neurons. ${ }^{3}$

Nogo-A is a well-studied inhibitory protein for axonal growth, plasticity and regeneration after CNS injury., Nogo-A is predominantly expressed in oligodendrocytes in the adult CNS, where it is thought to stabilize the neuronal circuits in healthy conditions and to inhibit neurite growth and plasticity after lesion. ${ }^{2}$ Neutralizing Nogo-A by functionblocking antibodies or genetic knockout (KO) has been shown to improve axonal sprouting and regeneration in the injured spinal cord and brain. ${ }^{6-11}$

In addition to oligodendrocytes and myelin, Nogo-A is expressed in growing and immature neurons, as well as in some adult neurons. ${ }^{12,13}$ Neurons express Nogo-A receptors such as the Nogo-66 receptor $1(\mathrm{NgR} 1)^{14}$ and the
Nogo-A- $\Delta 20$-specific sphingosine 1-phosphate receptor 2 (S1PR2). ${ }^{15}$ They can co-express them along with Nogo-A, ${ }^{13}$ an observation that raises the possibility of cis-interactions between the ligand and its receptors within or at the cell surface of the same cell. This mechanism has previously been described for axonal guidance molecules such as Ephrins and Semaphorins, and could have a major role in the neuronal response to extracellular growth inhibitors during development. ${ }^{16,17}$

In the adult CNS, the expression of neuronal Nogo-A remains elevated mainly in plastic regions such as in the hippocampus, olfactory bulb or neocortex, and in the dorsal root ganglia. ${ }^{12}$ Nogo-A and NgR1 were shown to regulate synaptic plasticity, for example, long-term potentiation in the hippocampus and in the sensory-motor cortex, ${ }^{18-22}$ whereas the effects of neuronal Nogo-A after injury are not yet well understood. During development, neuronal Nogo-A influences neuronal migration, ${ }^{23,24}$ survival, ${ }^{25,26}$ cell spreading and neurite growth. ${ }^{27,28}$ In injured adult retinal ganglion cells

\footnotetext{
${ }^{1}$ Brain Research Institute, University of Zurich, and Department of Health Sciences and Technology, ETH Zurich, CH-8057 Zurich, Switzerland; ${ }^{2}$ INSERM, U968, Paris, France; ${ }^{3}$ Sorbonne Universités, UPMC Univ Paris 06, UMR_S 968, Institut de la Vision, Paris, France; ${ }^{4} \mathrm{CNRS}$, UMR_7210, Paris F-75012, France and ${ }^{5}$ German Cancer Research Center (DKFZ), Heidelberg University, Heidelberg, Germany

${ }^{*}$ Corresponding authors: F Vajda, Brain Research Institute, University of Zürich, and Department of Health Sciences and Technology, ETH Zurich, Winterthurerstrasse, 190, Room 55J12, CH-8057 Zürich, Switzerland. Tel: +41 4463 53227; Fax: +41 4463 53303; E-mail: vajda @ hifo.uzh.ch

or V Pernet, CUO-Recherche, Centre de recherche du CHU de Québec de l'Université Laval, Hôpital St-Sacrement, Bureau H2-06, 1050 chemin Ste-Foy, Québec City, Québec, G1S 4L8, Canada. Tel: +1 418682 7511, ext 4568; E-mail: vincentpernet@fmed.ulaval.ca

Abbreviations: AAV, adeno-associated virus; AKT, protein kinase B; APC, adenomatous polyposis coli; CNPase, $2^{\prime}, 3^{\prime}$-cyclic nucleotide $3^{\prime}$-phosphodiesterase; CNS, central nervous system; CRALBP, cellular retinaldehyde binding protein; CREB, cAMP response element-binding protein; CTB-A594, cholera toxin B-Alexa594; DRG, dorsal root ganglion; ERK1/2, extracellular signal-regulated kinases 1/2; Gap-43, growth-associated protein 43; GAPDH, glyceraldehyde 3-phosphate dehydrogenase; GFP, green fluorescent protein; KO, knockout; MAG, myelin-associated glycoprotein; NgR1, Nogo66 receptor 1; ONC, optic nerve crush injury; PBS, phosphatebuffered saline; qRT-PCR, quantitative real-time polymerase chain reaction; RGC, retinal ganglion cell; RTN, reticulon; SOCS3, suppressor of cytokine signaling 3; S1PR2, sphingosine 1-phosphate receptor 2; Sprr1A, small proline-rich protein 1A; STAT3, signal transducer and activator of transcription 3; TBS, Tris-buffered saline Received 02.6.14; revised 15.8.14; accepted 18.8.14; Edited by N Bazan; published online 26.9.14
} 
(RGCs), silencing neuronal Nogo-A resulted in a marked reduction of regenerative sprouting and decreased expression of growth-associated molecules. ${ }^{29}$ Furthermore, in the optic nerve, axonal regeneration was not improved in conventional Nogo-A KO animals, in which both glial and neuronal Nogo-A were deleted. ${ }^{29}$ The present study therefore aimed to investigate whether glial and neuronal Nogo-A differently influence axonal growth in vivo using cell typespecific Nogo-A KO mouse lines and adeno-associated virus (AAV)-mediated recombination of the Nogo-A gene in neurons. The results show that significantly more axons grew through the lesion site in the oligodendrocyte-specific Nogo-A $\mathrm{KO}$ mice. In contrast, neuron-specific ablation of Nogo-A in RGCs reduced the number of regenerating axons after optic nerve crush injury (ONC). In summary, we show that inactivating Nogo-A specifically in oligodendrocytes appears to be the most successful strategy to promote axonal regeneration in the adult optic nerve.

\section{Results}

Targeted deletion of Nogo-A in oligodendrocytes. To obtain an oligodendrocyte-specific Nogo-A KO mouse line, mice expressing Cre-recombinase under the control of the $2^{\prime}, 3^{\prime}$-cyclic nucleotide $3^{\prime}$-phosphodiesterase $\left(\mathrm{Cnp}-\mathrm{Cre}^{+/-}\right)^{30}$ were crossed with mice in which exon 3 of the Rtn 4 gene was flanked by loxP sites (Rtn $4^{\text {flox/flox }}$ ) (Figure 1a). CNPase is a well-characterized component and marker for myelin and oligodendrocytes. ${ }^{31}$ In the optic nerve Olig2-positive oligodendrocytes specifically express CNP (Supplementary Figure S1A). By performing western blotting in the highly myelinated optic nerve, the level of Nogo-A protein decreased by $\sim 80 \%$ in Cnp-Cre ${ }^{+/-} \times R \operatorname{tn} 4^{\text {flox/flox }}$ mice compared with WT, Cnp-Cre ${ }^{+\prime-}$ and Rtn $4^{\text {flox/flox }}$ genotypes (Figure 1b). In the spinal cord, where Nogo-A is expressed in oligodendrocytes and in neurons, the level of Nogo-A was decreased by $\sim 70 \%$ (Figure 1c). In the neocortex of Cnp$\mathrm{Cre}^{+/-} \mathrm{xRtn} 4^{\text {flox/flox }}$ mice, Nogo-A levels were decreased by $\sim 50 \%$, reflecting the higher proportion of neuronal Nogo-A (Figure 1d). ${ }^{12}$ In the Cnp-Cre ${ }^{+/-} \times R \operatorname{tn} 4^{\text {flox/flox }}$ hippocampus, we observed $\sim 30 \%$ decrease in Nogo-A (Figure 1e). The level of the Nogo-A splice variant Nogo-B was elevated in the optic nerve, spinal cord, cortex and hippocampus, suggesting a compensatory upregulation of this protein in oligodendrocytes $^{7}$ (Figures $1 \mathrm{~b}-\mathrm{e}$ ). By immunohistochemistry in the optic nerve (Figure 1f) and corpus callosum (Figure 1g), adenomatous polyposis coli (APC)-positive oligodendrocytes were found to contain Nogo-A in control Cnp-Cre Cr- $^{+/-}$ animals, but lacked Nogo-A in Cnp-Cre ${ }^{+/-} \times R \operatorname{tn} 4^{\text {flox/flox }}$ mice.

Cnp-Cre-driven ablation of Nogo-A increases regenerative axonal sprouting after ONC. The effects of myelin Nogo-A on the regenerative growth of CNS axons were assessed in the optic nerve crush model. The retinal ganglion cell axon growth was analyzed after anterograde tracing with Alexa594-conjugated cholera toxin B on histological sections 2 weeks after injury. We observed more axonal sprouting after the lesion site in Cnp-Cre ${ }^{+/-} \times R \operatorname{tn} 4^{\text {flox/flox }}$ mice than in the control groups (Figure 2a). Quantitatively, compared with control genotypes the Cnp-Cre ${ }^{+/-} \times R \operatorname{tn} 4^{\text {flox/flox }}$ optic nerves showed more regenerating axons at 50, 100, 150 and $200 \mu \mathrm{m}$ past the injury site (Figure $2 \mathrm{~b}$ ). The injury-induced growth response of RGCs was further analyzed by following the gene expression changes of Sprr1A and growth-associated protein 43 (Gap-43), two known indicators of neuronal growth in the CNS and the peripheral nervous system..$^{29,32-34}$ The mRNA levels of the two growth markers were increased 5 days after optic nerve crush and were more elevated in the Cnp-Cre ${ }^{+/-}$ $\mathrm{x} R \operatorname{tn} 4^{\text {flox/flox }} \mathrm{KO}$ retinae than in control samples (Supplementary Figures S2A and B). These data show that the targeted deletion of Nogo-A in myelinating cells of the optic nerve enhances the neuronal growth response after axonal injury, in marked contrast with our previous analysis in conventional, systemic Nogo-A KO animals. ${ }^{29}$

Nogo-A deletion in Cnp-Cre ${ }^{+I-} \times R \operatorname{Rn} 4^{\text {flox/flox }}$ mice enhances inflammation-induced axonal regeneration after optic nerve injury. The growth state of RGCs can be enhanced by intraocular injection of inflammatory agents such as the Toll-like receptor 2 agonist Zymosan. ${ }^{35,36}$ In our study, we observed that the injection of Zymosan at the time of the injury increased the number of regenerating axons by $\sim 3$-fold in all the groups compared with untreated mice. The enhancement of growing axons was higher in the optic nerves of Cnp-Cre ${ }^{+/-} \times R \operatorname{tn} 4^{\text {flox/flox }}$ mice than in WT, Cnp$\mathrm{Cre}^{+/-}$or Rtn ${ }^{\text {flox/flox }}$ animals (Figures 2c and d). Statistically more axonal fibers grew across the lesion site in the Cnp-Cre ${ }^{+/-} \times R_{\text {tn }} 4^{\text {flox/flox }} \mathrm{KO}$ mice at 50, 100, 150, 200 and $300 \mu \mathrm{m}$ past the injury site than in the control genotypes (Figure 2d). These results show that the combined growth program stimulation with a pro-inflammatory molecule along with the deletion of Nogo-A myelin potentiates axonal regeneration.

Three-dimensional analysis of the growth pattern of regenerating axons in the transparent optic nerve. The higher numbers of retinal fibers in Cnp-Cre ${ }^{+/}-\mathrm{xRtn} 4^{\text {flox/flox }}$ optic nerves elongating after the injury site could either be due to a higher number of individually growing axons or due to enhanced branching. In order to assess the pattern of growing axons, a three-dimensional analysis of the regenerating fibers was carried out in whole-mounted optic nerves after tissue clearing using a modified protocol previously described. ${ }^{37,38}$ In the optic nerve segments situated between 100 and $300 \mu \mathrm{m}$ past the lesion site, branched and unbranched axons could be distinguished, as well as axons that formed U-turns within this region (Figures $2 e$ and f). We found that the proportion of branching axons did not significantly vary between Cnp-Cre ${ }^{+/-} \times R \operatorname{tn} 4^{\text {flox/flox }}$ and $R t n 4^{\text {flox/flox }}$ control mice (Figure $2 \mathrm{~g}$ ). The percentage of U-turn-forming axons was not different between the two genotypes (Figure 2h).

Compensatory upregulation of EphrinA3 and EphA4

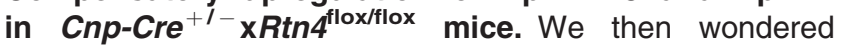
whether compensatory mechanisms impede axonal regeneration in Cnp-Cre ${ }^{+/-} \times R \operatorname{tn} 4^{\text {flox/flox }}$ mice after crush lesion. Our laboratory has previously found that Nogo-A gene deletion induced the upregulation of inhibitory molecules such as EphA4 and one of its ligands EphrinA3 in the spinal cord. ${ }^{39}$ 
a

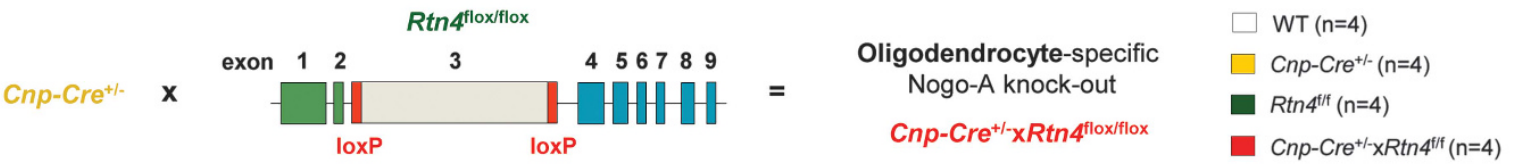

b

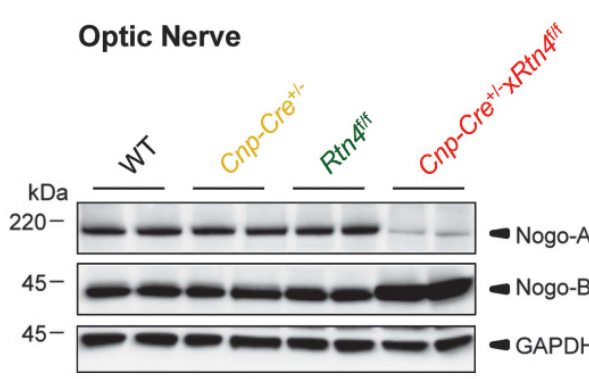

d

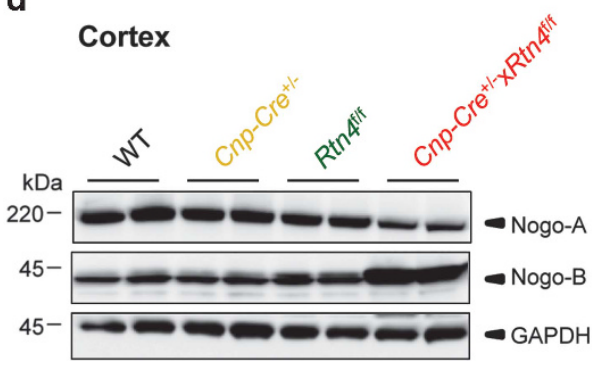

Optic Nerve

Cnp-Cre ${ }^{+/-}$

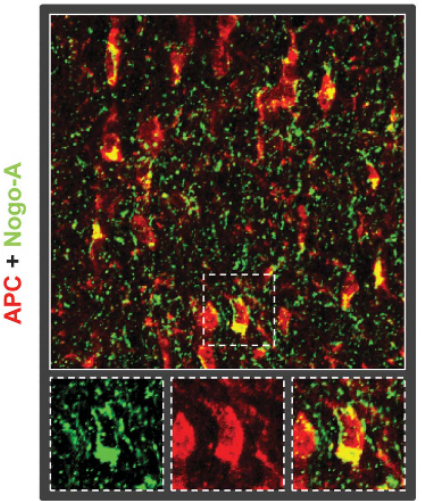

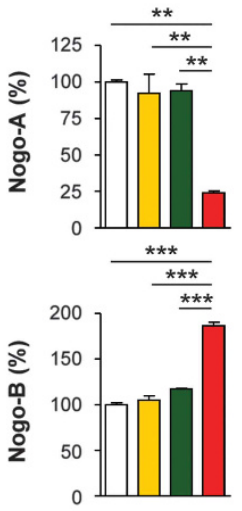

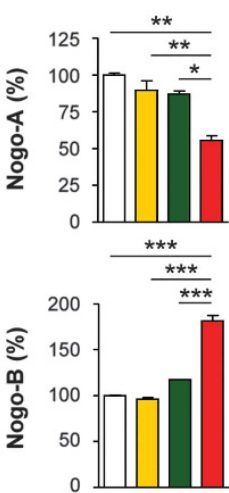

C
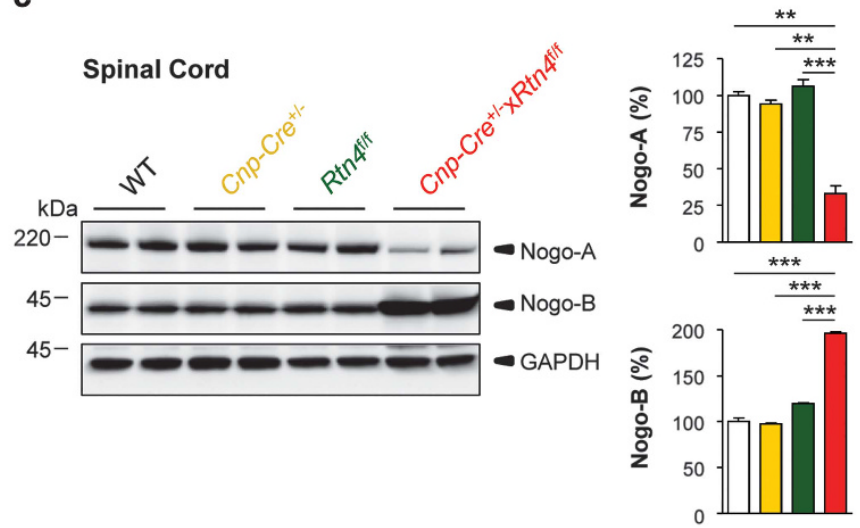

e
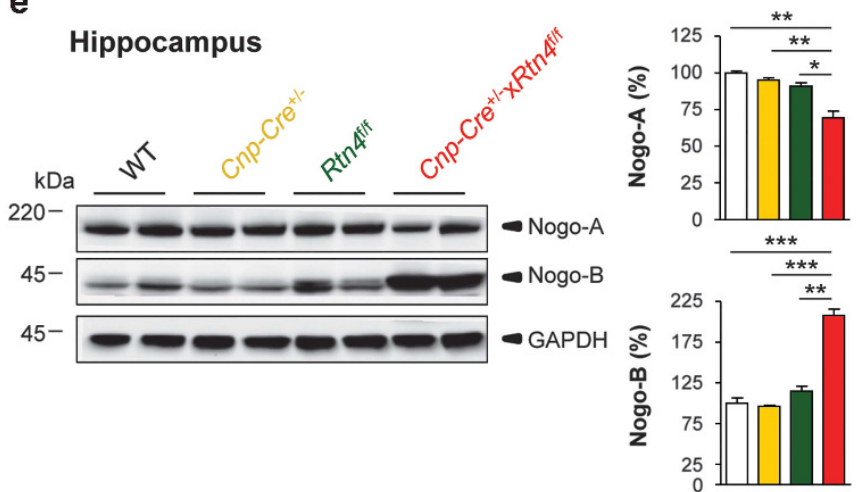

g

Corpus Callosum

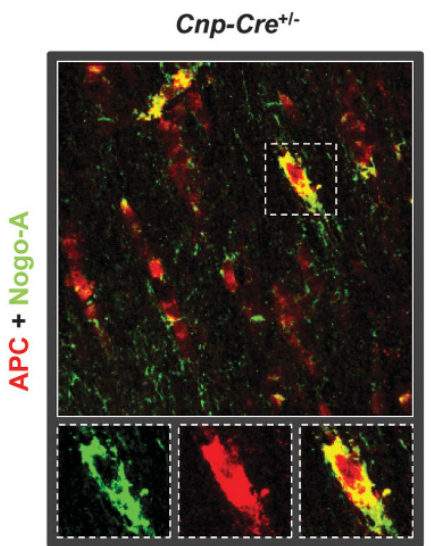

Cnp-Cre ${ }^{+/} \times \operatorname{Rtn}^{\text {f/f }}$
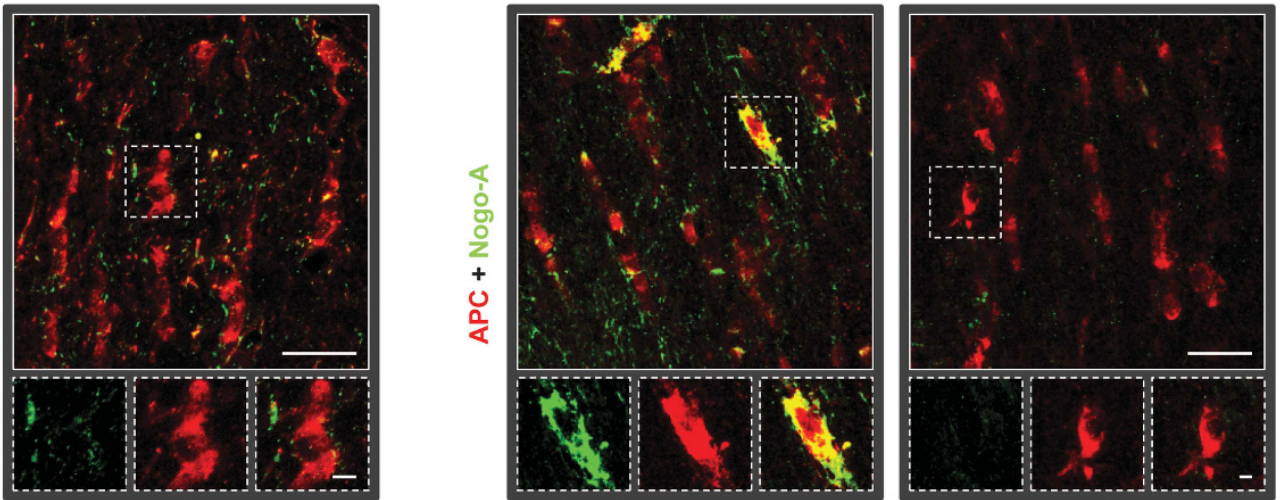

Figure 1 Generation and characterization of Cnp-Cre ${ }^{+/}-x R_{t n} 4^{\text {floxflox }}$ Nogo-A KO animals. (a) To obtain an oligodendrocyte-specific Nogo-A KO mouse line, mice expressing Cre-recombinase under the control of the $2^{\prime}, 3^{\prime}-\mathrm{Cnp}^{30}$ were crossed with mice in which exon 3 of the Rtn4 gene was flanked by loxP sequences (Rtn $4^{\text {floxfliox }}$ ). (b-e) Western blot analysis revealed that Nogo-A protein was downregulated in the optic nerve ( $\sim 80 \%)$, spinal cord ( 70\%), cortex ( 50\%) and hippocampus ( 30\%) to different extents. In all these four examined CNS regions Nogo-B protein showed compensatory upregulation. (f and $\mathbf{g}$ ) By double immunohistochemistry for Nogo-A and APC on the optic nerve and corpus callosum sections, Nogo-A was specifically excised from oligodendrocytes in myelinated regions. APC-positive oligodendrocytes contained Nogo-A only in control animals and lacked Nogo-A in the Cnp-Cre ${ }^{+1}-x R t n 4^{\text {floxflox }} \mathrm{KO}$ mice. Fluorescent pictures were from merged confocal microscopy stacks. Statistics: one-way ANOVA, Bonferroni's multiple comparison test, ${ }^{*} P<0.05,{ }^{* *} P<0.01,{ }^{* \star} P<0.001$. Scale bars: $(\mathbf{f}, \mathbf{g})=25 \mu \mathrm{m}$; insets $=5 \mu \mathrm{m}$ 
In EphA4 KO mice, axonal growth was increased in the injured spinal cord and optic nerve compared with WT animals. ${ }^{39,40}$ In the present study, the analysis of EphrinA3 and EphA4 expressions by western blotting revealed a strong upregulation of EphrinA3 in the optic nerve and an increase of EphA4 in the retina of Cnp-Cre ${ }^{+-} \mathrm{xRtn} 4^{\text {flox/flox }}$ a

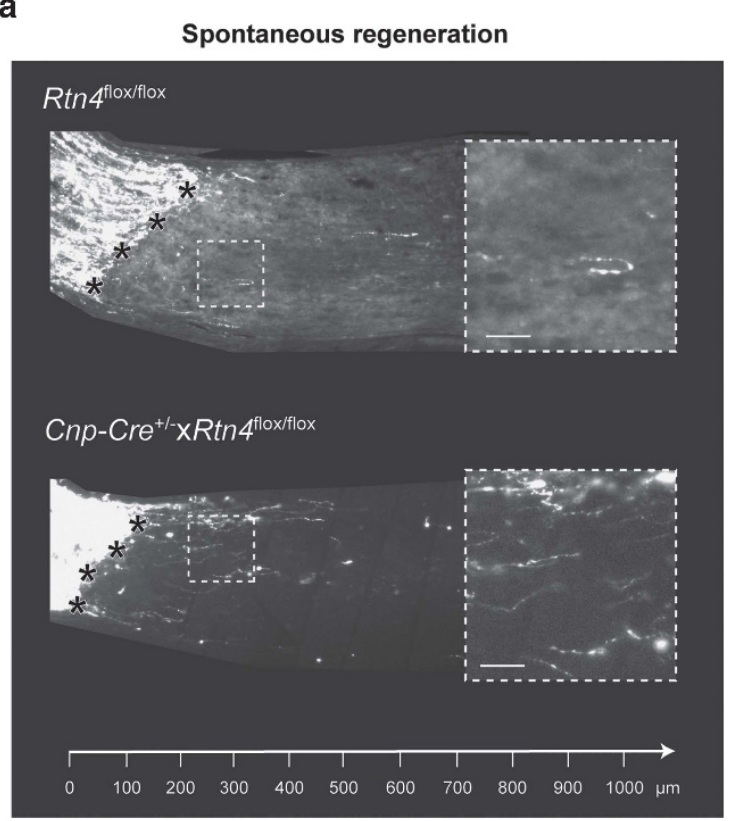

b

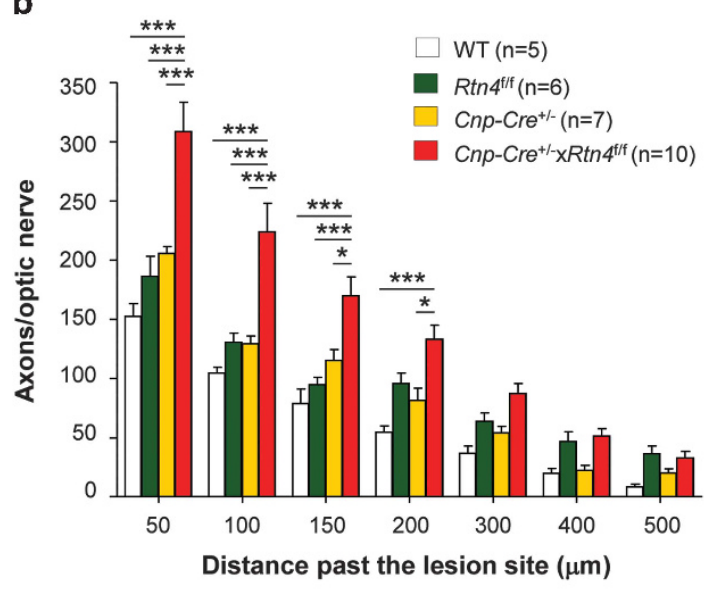

e

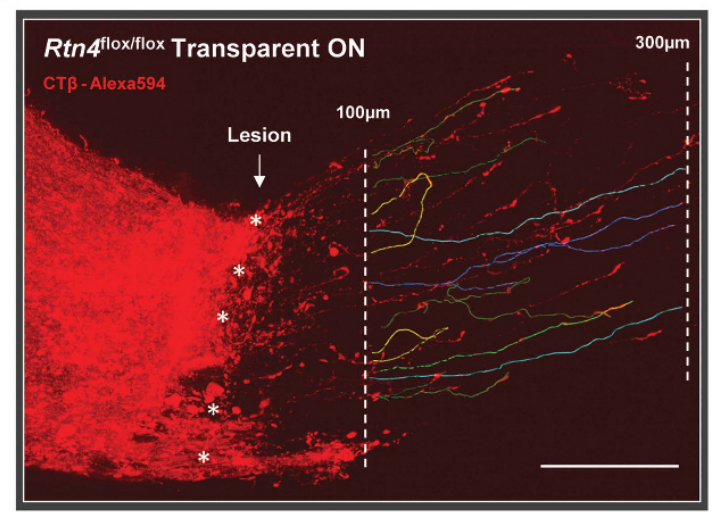

C

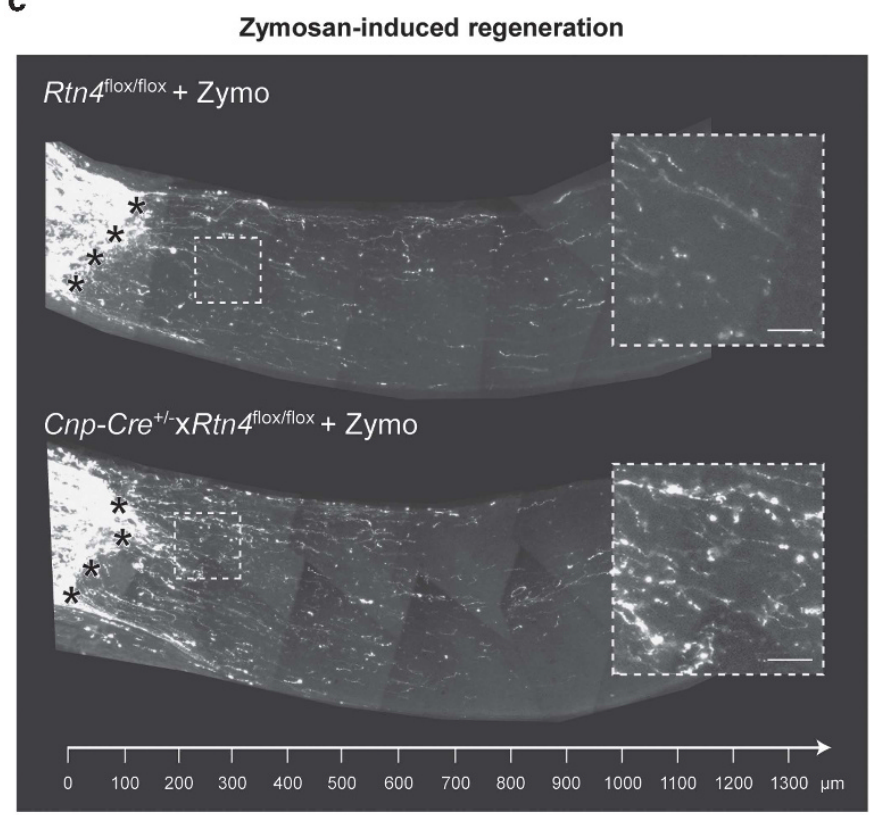

d

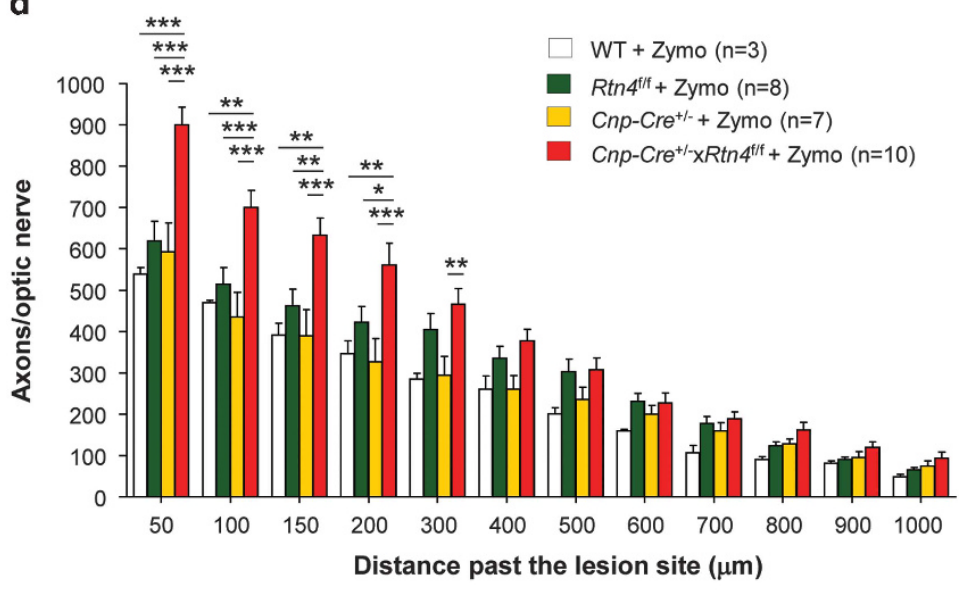

f

g

h
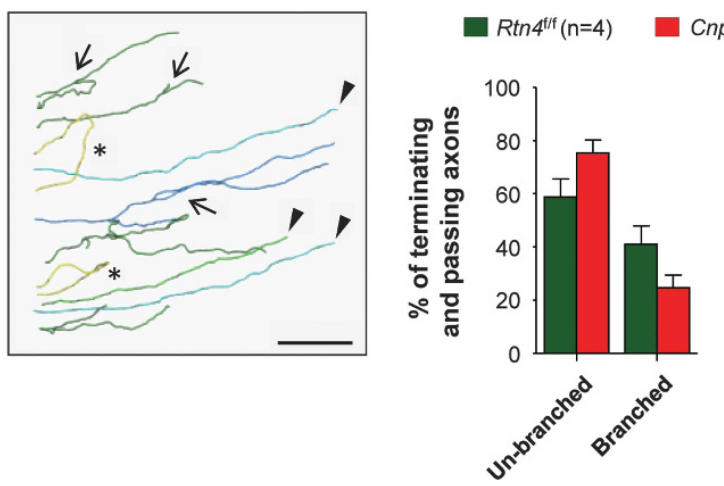
compared with Cnp-Cre ${ }^{+/-}$mice (Supplementary Figures S3A and E). In contrast, myelin-associated glycoprotein (MAG), a molecule that can block axonal regeneration by activating the same receptor (NgR1) as Nogo-A, ${ }^{41}$ did not change in optic nerves (Supplementary Figure S3B). The retinal expressions of $\mathrm{NgR} 1$ and S1PR2, a newly identified receptor for Nogo-A, ${ }^{15}$ were not modified (Supplementary Figure S5A and Supplementary Figure S3C and F). These data suggest that EphA4 and EphrinA3 upregulation may restrict the distance of axonal regrowth in Cnp-Cre ${ }^{+/-} \times R \operatorname{tn} 4^{\text {flox/flox }}$ optic nerves following injury.

Nogo-A distribution and neuronal survival in the retinae of Cnp-Cre ${ }^{+I-} \times R_{\text {tn }} 4^{\text {flox/flox }}$ mice. Western blot analysis revealed a downregulation of Nogo-A by $\sim 85 \%$ in glial NogoA KO retinae (Figure $3 \mathrm{a}$ ), although no oligodendrocytes are present in this tissue. As in the intact retina of adult mice the bulk of Nogo-A is expressed by Müller glial cells, ${ }^{29}$ we hypothesized that Nogo-A downregulation may be derived from expression changes occurring in these cells. In fact, quantitative real-time polymerase chain reaction (qRT-PCR) measurements showed a transitory expression of Cnp mRNA in the postnatal retina (Supplementary Figure S1B). By immunohistochemistry, the CNP protein was localized in Müller cell processes labelled with the specific marker cellular retinaldehyde binding protein (CRALBP) at $\mathrm{P} 8$ (Figure 3e). Nogo-B levels were not changed in Cnp-Cre ${ }^{+/-}$ $\mathrm{x} R \operatorname{tn} 4^{\text {flox/flox }}$ retinae (Figure $3 \mathrm{a}$ ). Compared with the intact, control mouse retinal flat-mounts, in which Nogo-A appeared mostly in the end-feet of Müller cells around $\beta$ III-Tubulinlabelled retinal ganglion cell bodies, Nogo-A expression was abolished in the Müller cells of Cnp-Cre ${ }^{+/-} \times R_{t n} 4^{\text {flox/flox }} \mathrm{KO}$ retinae (Figure $3 b$ ). Strikingly, in the same retinae, Nogo-A was clearly upregulated in RGCs. Quantitatively, in intact control retinae $\sim 7 \%$ of RGCs expressed Nogo-A, whereas in the intact Cnp-Cre ${ }^{+l-} \times R_{\text {tn }} 4^{\text {flox/flox }}$ KOs $\sim 55 \%$ of RGCs showed a bright signal for the Nogo-A protein (Figure $3 c$ ). Two weeks after ONC, the proportion of cells expressing Nogo-A rose to $\sim 50 \%$ in the surviving retinal ganglion cell bodies of $R \operatorname{tn} 4^{\text {flox/flox }}$ control mice, but remained at $\sim 55 \%$ in $\mathrm{Cnp}-\mathrm{Cre}^{+/-} \mathrm{xRtn} 4^{\text {flox/flox }}$ animals, a percentage that did not differ from the intact condition (Figure $3 d$ ). The density of the surviving $\beta$ III-Tubulin-positive RGCs was examined 2 weeks after ONC on retinal flat-mounts (Figure $3 f)$. The retinal ganglion cell survival was slightly, but significantly increased in Cnp-Cre ${ }^{+/-} \times R \operatorname{tn} 4^{\text {flox/flox }}$
$\mathrm{KO}$ animals compared with the control genotypes, from $\sim 25 \%$ in Rtn $4^{\text {flox/flox }}$ control to $\sim 33 \%$ in Cnp-Cre Crl- $^{+1}$ $\mathrm{x} R \operatorname{tn} 4^{\text {floxflox }} \mathrm{KO}$ retinae (Figure $3 \mathrm{~g}$ ).

Nogo-A expression is required in RGCs for optic axon regeneration. We selectively ablated Nogo-A in RGCs of Rtn $4^{\text {flox/flox }}$ mice by infection with an AAV serotype 2 containing the Cre cDNA (AAV2.Cre). After 4 weeks of incubation, AAV2.Cre infection reduced the number of NogoA-expressing RGCs in intact Cnp-Cre ${ }^{+1-} \times R_{t n} 4^{\text {flox/flox }}$ mice from $\sim 55$ to $\sim 30 \%$ (Supplementary Figures S4A and B). The injury-induced upregulation of Nogo-A at days 5 and 14 was markedly reduced in retinal ganglion cells transduced with AAV2.Cre in Rtn $4^{\text {flox/flox }}$ animals, from $50 \%$ Nogo-Apositive, surviving cells in WT mice to $\sim 15 \%$ in the knockdown retinae at the two time points (Figures $4 a-c$ ). In Cnp-Cre ${ }^{+/-} \mathrm{xRtn} 4^{\text {flox/flox }}$ mice, the percentage of Nogo-Aexpressing RGCs decreased from $\sim 55 \%$ in intact retinae to $\sim 25 \%$ at 2 weeks after nerve crush (Figure 4c). The knockdown of Nogo-A in the RGCs resulted in a statistically lower number of sprouting fibers at 2 weeks post injury compared with WT mice injected with AAV2.Cre. Moreover, AAV2.Cre injection in Cnp-Cre ${ }^{+/-} \mathrm{xRtn} 4^{\text {flox/flox }}$ mice completely prevented the enhancement of regenerative sprouting that we observed in these animals without the AAV2.Cre injection (Figure 4d).

To genetically ablate Nogo-A in RGCs, a neuron-specific Nogo-A KO mouse line was generated by crossing mice expressing Cre-recombinase under the control of the Thy 1 promoter $^{42}$ with $R \operatorname{tn} 4^{\text {flox/flox }}$ mice (Figure $5 \mathrm{a}$ ). By western blotting in the optic nerve, neuronal KOs showed a Nogo-A reduction by $\sim 40 \%$ compared with $\sim 80 \%$ downregulation in glial KOs (Figure $5 \mathrm{~b}$ ). In the primary motor cortex, Nogo-A was reduced by $\sim 40 \%$ in glial and by $\sim 70 \%$ in neuronal KOs (Figure $5 \mathrm{c}$ ). As shown before, compared with the glial Nogo-A KO retinae where Nogo-A expression was reduced by $\sim 90 \%$, we found $\sim 40 \%$ reduction of Nogo-A in the neuron-specific KO retinae (Figure $5 \mathrm{~d}$ ). Importantly, regenerative axonal sprouting was decreased in neuronal Nogo-A KO mice after optic nerve injury with respect to Rtn $4^{\text {flox/flox }}$ mice. Quantitatively, the number of axons growing through the lesion was statistically diminished in Thy $1-C r e^{\text {tg }+} \times R \operatorname{tn} 4^{\text {flox/flox }}$ animals at 50 and $100 \mu \mathrm{m}$ past the injury site compared with the control Rtn $4^{\text {flox/flox }}$ group (Figure 5e). Thy $1-C r e^{\text {tg }}+$ control mice showed the same protein expression levels for Nogo-A and Nogo-B in all

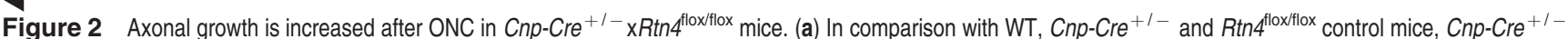
$x R \operatorname{tn} 4^{\text {floxfllox }}$ mice showed significantly more growing CTB-594-labelled fibers across the optic nerve lesion site (black stars). (b) The number of growing axonal fibers was statistically higher in Cnp-Cre ${ }^{+l}-x R t n 4^{\text {floxfflox }}$, glia-specific Nogo-A KOs (mean \pm S.E.M., two-way ANOVA, Bonferroni post test, ${ }^{\star} P<0.05,{ }^{\star *} P<0.01,{ }^{* \star \star} P<0.001$ ) at 50 , 100,150 and $200 \mu \mathrm{m}$ past the injury site. (c) The intraocular delivery of pro-inflammatory reagent Zymosan at the time of the lesion placed RGCs in an active growth state resulting in robust axonal growth in the injured optic nerve. (d) In the optic nerves of mice injected with Zymosan, CTB-594-labelled regenerating fibers were dramatically increased in all genotypes, but were the most abundant in Cnp-Cre ${ }^{+/-} \times R \operatorname{tn} 4^{\text {floxflox }}$ animals. Statistically more axons grew across the lesion site in the Cnp-Cre ${ }^{+/-} \times R \operatorname{tn} 4^{\text {floxfllox }}$, glial Nogo-A KO mice (mean \pm S.E.M., two-way ANOVA, Bonferroni's post test, ${ }^{*} P<0.05,{ }^{\star \star} P<0.01,{ }^{* \star *} P<0.001$ ) at $50,100,150,200$ and $300 \mu$ m past the injury site than in control genotypes. (e) Tissue clearing allowed to visualize traced axons in three dimensions in transparent whole-mounted optic nerves 2 weeks after injury (lesion site: stars). An example of a 3D optic nerve segment is presented for a control Rtn $4^{\text {floxfliox }}$ mouse after reconstruction of confocal microscopy image stacks with the Imaris software. Axons were analyzed at high magnification in the region where Cnp-Cre ${ }^{+1-} x R t n 4^{\text {flox/lox }}$ mice had more sprouting axons, i.e. between 100 and $300 \mu \mathrm{m}$ past the injury site (two dashed lines). (f) In this range, branched (arrows), un-branched (arrowheads) and U-turn-forming (stars) axons could be identified. (g) The proportion of branching axons did not significantly vary between $R \operatorname{tn} 4^{\text {floxfllox }}$ and $\mathrm{Cnp}-\mathrm{Cre}^{+l-} \mathrm{xRtn} 4^{\text {floxflox }}$ mice. (h) The percentage of U-turn-forming axons was not different between the two genotypes. Scale bars: (a, c) insets $=25 \mu \mathrm{m} ;(\mathbf{e})=100 \mu \mathrm{m},(\mathbf{f})=50 \mu \mathrm{m}$ 
a

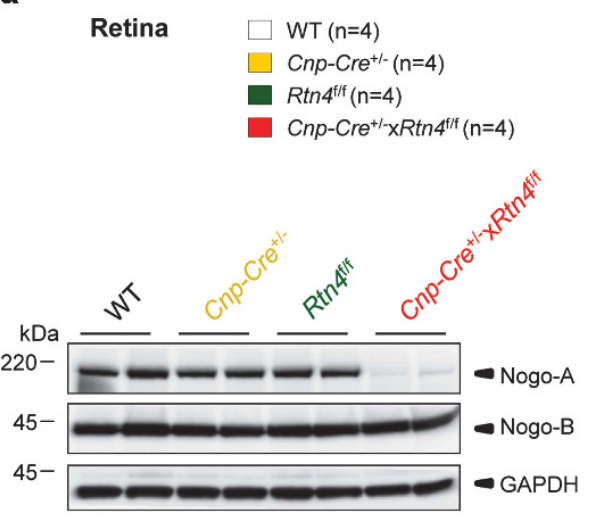

b

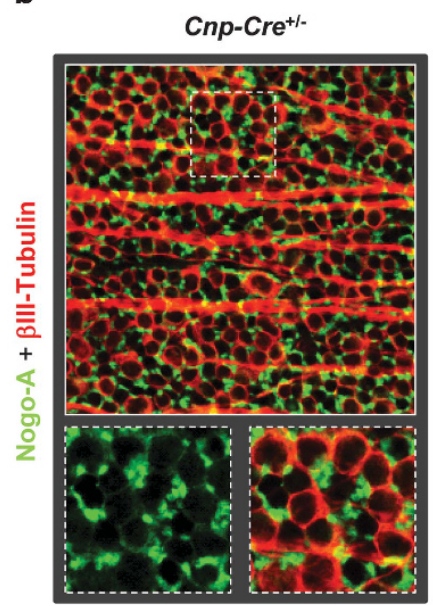

f

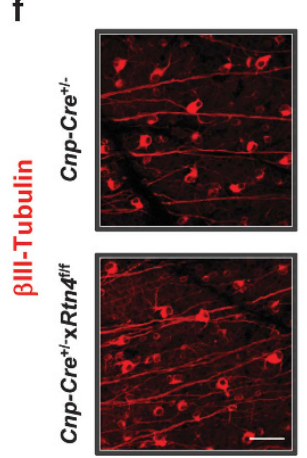

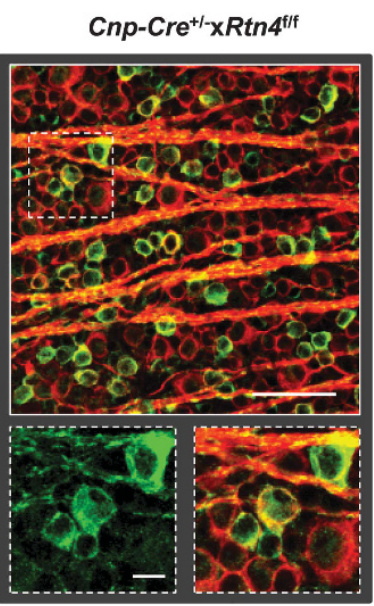

g

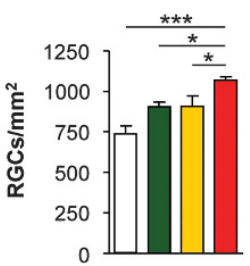

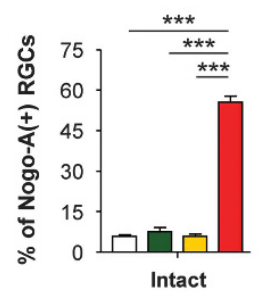

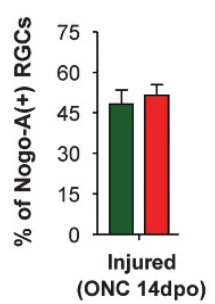

e

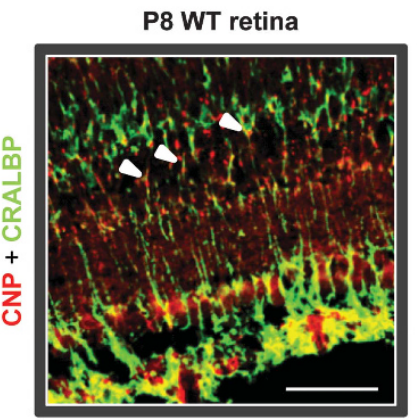

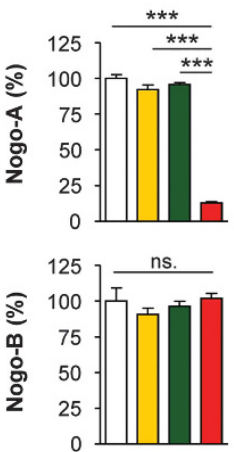

d

Figure 3 Retinal ganglion cell body analysis reveals Nogo-A upregulation and higher cell survival in Cnp-Cre ${ }^{+I-}$ xRtn $4^{\text {floxfllox }}$ KOs. (a) In the retina, Nogo-A expression was downregulated by $\sim 85 \%$, whereas Nogo-B was unchanged in the Cnp-Cre ${ }^{+1-}$ xRtn $4^{\text {flox/flox }} \mathrm{KO}$. (b) In intact, Cnp-Cre ${ }^{+/}$- control retinae, Nogo-A was mostly located in Müller cell end-feet surrounding $\beta$ III-Tubulin-labelled retinal ganglion cell bodies. In contrast, in Cnp-Cre ${ }^{+1-} \mathrm{xRtn} 4^{\text {floxfllox }} \mathrm{KOs}$, Nogo-A expression was abolished in Müller cells and was strongly upregulated in RGCs. (c) Quantitatively, 7\% of RGCs expressed Nogo-A in intact control retinae, whereas 55\% of RGCs expressed the Nogo-A protein in the glial Nogo-A KOs ( $n=4$ per group). (d) Two weeks after ONC injury the density of RGCs expressing Nogo-A was not significantly different between Rtn 4 floxfllox and Cnp-Cre ${ }^{+l-} \times R \operatorname{Rn} 4^{\text {floxfllox }}$ mice ( $n=3$ per group). (e) In the retina, the CNP protein was expressed in Müller cells identified by using the cell-type specific marker CRALBP. (f) Two weeks after injury, the density of surviving RGCs was evaluated by immunostaining for $\beta$ III-Tubulin on retinal flat-mounts. (g) Retinal ganglion cell survival was slightly, but significantly increased in Cnp-Cre ${ }^{+1-} \times R_{t n} 4^{\text {floxfllox }} \mathrm{KO}$ animals compared with the control genotypes $(n=3-7)$. Statistics: one-way ANOVA, Bonferroni's multiple comparison test, ${ }^{*} P<0.05,{ }^{* *} P<0.01,{ }^{* *} P<0.001$. Scale bars: (b, e, f) $=50 \mu \mathrm{m}$; (b) insets $=10 \mu \mathrm{m}$

examined CNS regions and similar axon regeneration (data not shown) as Rtn $4^{\text {flox/flox }}$ animals.

The immunohistochemical signal for the Nogo receptor NgR1 is increased in $\mathrm{Cnp}-\mathrm{Cre}^{+/-} \times \mathrm{Rtn}^{\text {flox/flox }}$ retinae. $\mathrm{NgR} 1$ is a well-characterized GPI-linked Nogo-A receptor expressed by intact RGCs in Rtn4 ${ }^{\text {flox/flox }}$ control and Cnp$\mathrm{Cre}^{+/-} \mathrm{xRtn} 4^{\text {flox/flox }} \mathrm{KO}$ mice (Figure 6a). By immunohistochemistry in intact retinal flat-mounts, the level of the $\mathrm{NgR} 1$ protein detected in the retinal ganglion cell bodies was found to be higher in the neurons that expressed a higher level of Nogo-A compared with cells that showed weak Nogo-A signal in the Cnp-Cre ${ }^{+/-} \mathrm{xRtn} 4^{\text {flox/flox }} \mathrm{KO}$ animals (Figures $6 \mathrm{~b}$ and $\mathrm{c}$ ). The overall mRNA expression level of $\mathrm{NgR} 1$, however, was not different between the two genotypes in intact and injured conditions (Supplementary Figure 5A). The Nogo-A mRNA level reduction was also confirmed with qRT-PCR experiments (Supplementary Figure 5B). We hypothesized that the stronger $\mathrm{NgR} 1$ signal observed by immunohistochemistry could reflect the increased association of Nogo-A with NgR1 in Nogo-A-positive RGCs. This close proximity could lead to a cis-interaction between the ligand and its receptor intracellularly or on the cell membrane and potentially lead to the attenuation of trans-Nogo-A signaling (Figures $6 f$ and $\mathrm{g}$ ). To test this hypothesis, the activation of the downstream Nogo-A/NgR1 signaling mediator Rho-A was studied in Rho-A-GTP pull-down experiments. In the intact conditions where the Rho-A signaling pathway is not activated, no differences could be detected in Rho-A-GTP levels between Rtn $4^{\text {flox/flox }}$ control and $\mathrm{Cnp}-\mathrm{Cre}^{+/-} \mathrm{xRtn} 4^{\text {flox/flox }} \mathrm{KO}$ retinae. However, after ONC, significantly less Rho-A-GTP was detected in the retinae of the $\mathrm{Cnp}-\mathrm{Cre}^{+/-} \mathrm{xRtn} 4^{\text {flox/flox }}$ mice than in samples collected from control animals (Figures $6 \mathrm{~d}$ and e). Downstream of Rho-A, the level of the inactive, phosphorylated form of the actin filament severing enzyme Cofilin was however not changed in $\mathrm{Cnp}-\mathrm{Cre}^{+/-} \times \mathrm{Rtn}^{\text {flox/flox }}$ retinae (Supplementary Figures S6A-C). None of the regeneration 
a

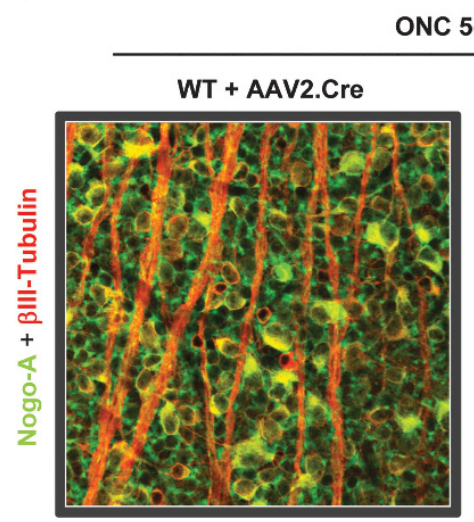

b

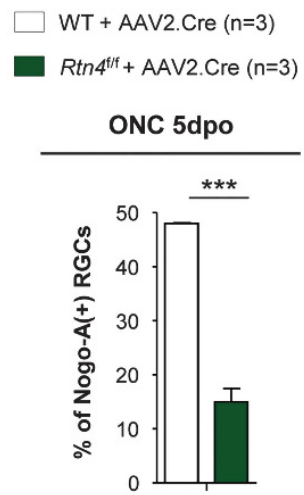

c

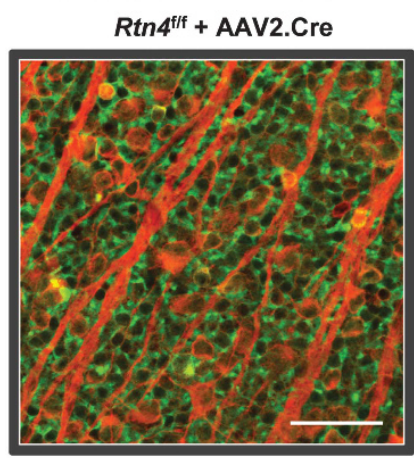

d
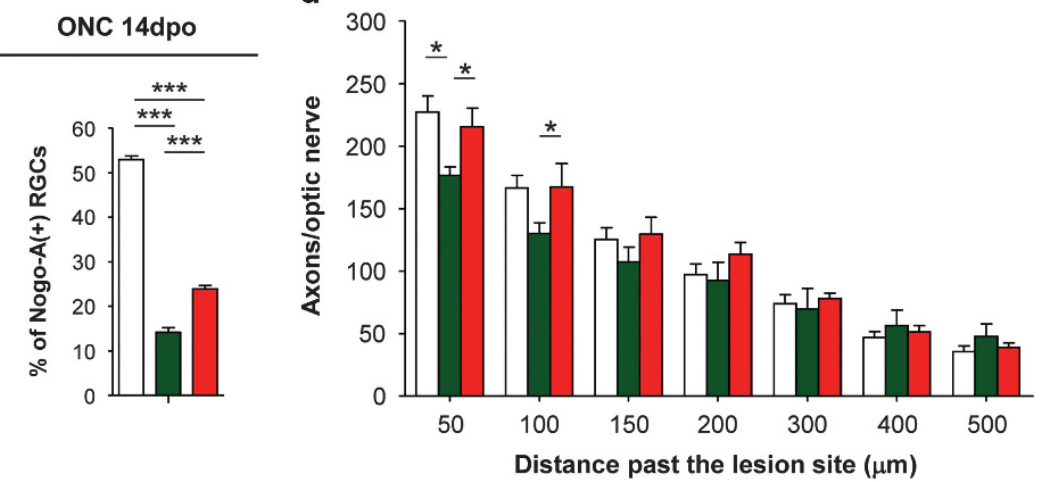

$W T+A A V 2 . C r e(n=6)$

$R \operatorname{tn} 4^{f / f}+$ AAV2.Cre $(n=6)$

$\mathrm{Cnp}-\mathrm{Cre}^{+/-} \mathrm{xRtn} 4^{\mathrm{f} / \mathrm{f}}+\mathrm{AAV} 2 . \mathrm{Cre}(\mathrm{n}=6)$

Figure 4 Neuronal Nogo-A ablation in retinal ganglion neurons reduces axonal sprouting in the injured optic nerve. (a, b) WT and Rtn4 $4^{\text {flox/flox }}$ mice were intraocularly injected with AAV2.Cre virus 4 weeks before ONC. Five days after crush operation (5dpo), Nogo-A was detected in $\sim 50 \%$ of RGCs in WT animals. In contrast, the proportion of injured RGCs expressing Nogo-A was reduced to $\sim 15 \%$ after transduction with AAV2.Cre virus in Rtn $4^{\text {flox/flox }}$ animals. (c) Two weeks after injury $\sim 52 \%$ of RGCs expressed Nogo-A in WT control mice, whereas only $\sim 15 \%$ of surviving RGCs contained Nogo-A in AAV2.Cre-injected Rtn $4^{\text {flox/flox }}$ mice, and $\sim 25 \%$ of RGCs were positive for Nogo-A in AAV2.Cre-injected Cnp-Cre ${ }^{+1-} \mathrm{xRtn} 4^{\text {flox/flox }} \mathrm{KOs}$. (d) For the axonal regeneration study, the AAV2.Cre virus was injected 4 weeks before the ONC and the number of CTB-A594-positive fibers was counted 2 weeks after injury. Quantitatively, compared with WT mice injected with AAV2.Cre, the number of axons growing after

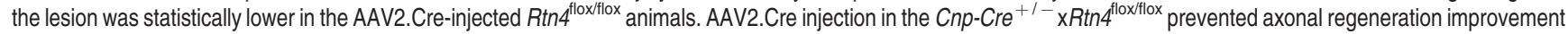
in glial-Nogo-A KOs (mean \pm S.E.M., two-way ANOVA, Bonferroni post test, $\left.{ }^{*} P<0.05\right)$. Scale bar: (a) $=50 \mu \mathrm{m}$

and survival-related signaling pathways such as the CAMP response element-binding protein (CREB), extracellular-signal-regulated kinase 1/2 (ERK1/2), signal transducer and activator of transcription 3 (STAT3) and protein kinase B (AKT) analyzed by western blotting (Supplementary Figures S6D-M) and immunohistochemistry (Supplementary Figures S6C, Fand I) showed significant difference between control and Cnp-Cre ${ }^{+/-} \times R_{t n} 4^{\text {flox/flox }}$ retinae.

In vitro, the role of neuronal Nogo-A was tested by plating dorsal root ganglion (DRG)-derived F11 cells on substrates coated with increasing concentrations of the Nogo-A inhibitory fragment Nogo-A-delta20 $(\Delta 20)$; Nogo-A inhibited neurite outgrowth in a concentration-dependent way (Supplementary Figure S7B). Overexpression of Nogo-A in the F11 cells by AAV2.Nogo-A attenuated the inhibition of neurite outgrowth on the Nogo-A- $\Delta 20$ substrate (Supplementary Figures S7A and $B$ ). This result suggests a cell-autonomous effect of neuronal Nogo-A on neurite outgrowth and supports the possibility that cis-interaction between Nogo-A and its receptors may counteract the inhibitory effect of Nogo-A present in the environment.

\section{Discussion}

In the present study we aimed to investigate whether glial and neuronal Nogo-A differently influence axonal growth in vivo. We created cell type-specific Nogo-A KO mouse lines and applied AAV-mediated recombination of the Nogo-A gene in neurons. Our results show that axonal sprouting is significantly increased in the optic nerves of oligodendrocytespecific Nogo-A KO mice and accompanied by a decrease in Rho-A activation in the retina.

Axonal regeneration in conventional versus cell type-specific Nogo-A KO lines. The characterization of Cnp-Cre ${ }^{+/-} \mathrm{xRtn} 4^{\text {flox/flox }}$ mice (glial Nogo-A KO mice) revealed oligodendrocyte-specific ablation in myelinated CNS regions and deletion of Nogo-A from Müller glial cells in the retina. In these mice, axonal regeneration was increased compared with control animals, in line with the effects obtained by acute pharmacological treatments such as the anti-Nogo-A antibody infusion, the application of the soluble NgR1 decoy receptor, or Rho-A/Rho-associated 
a

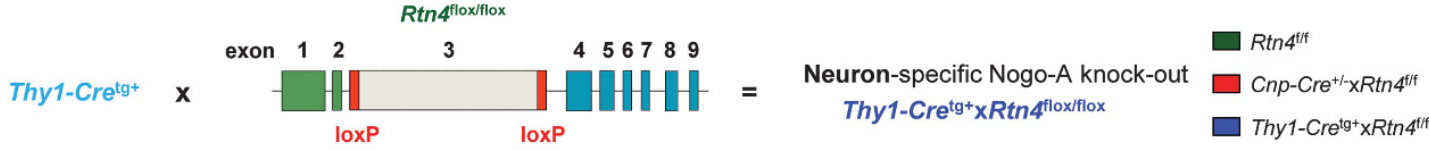

b
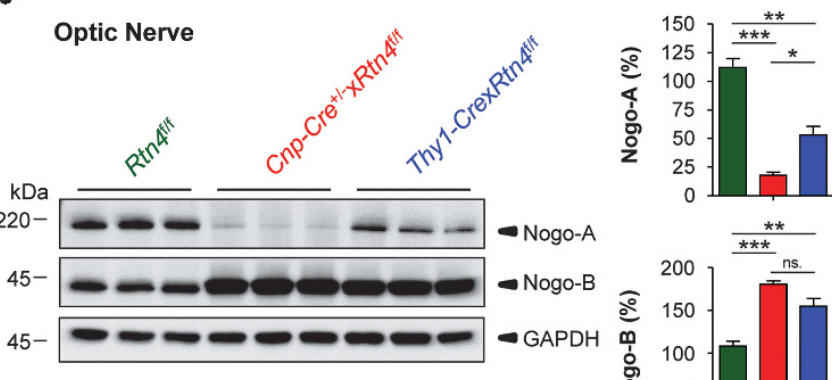

c
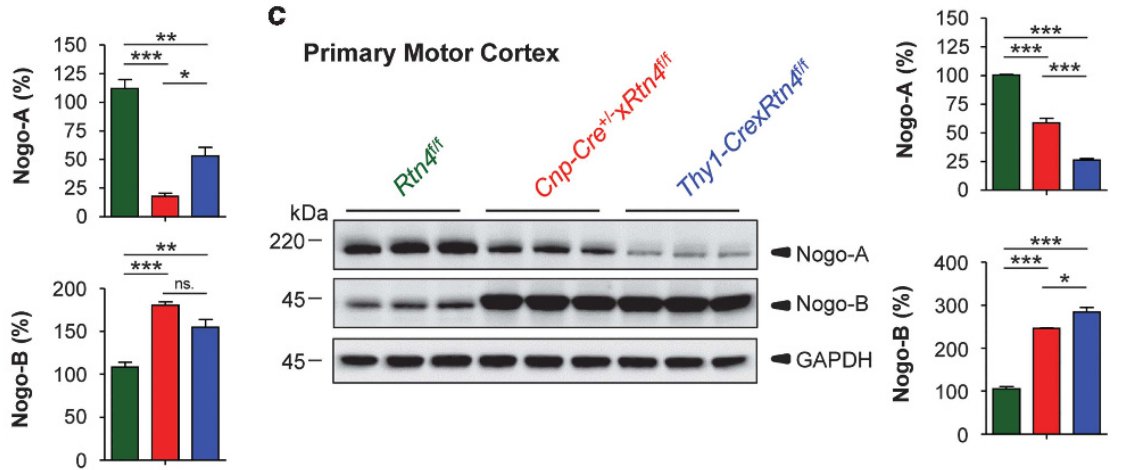

d
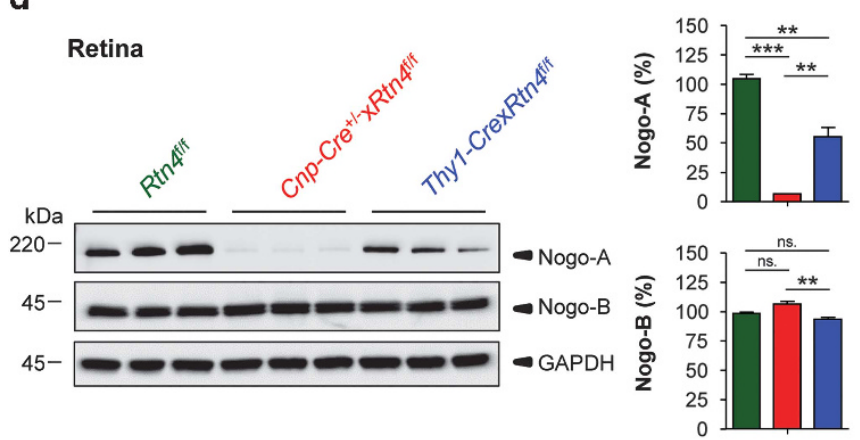

e

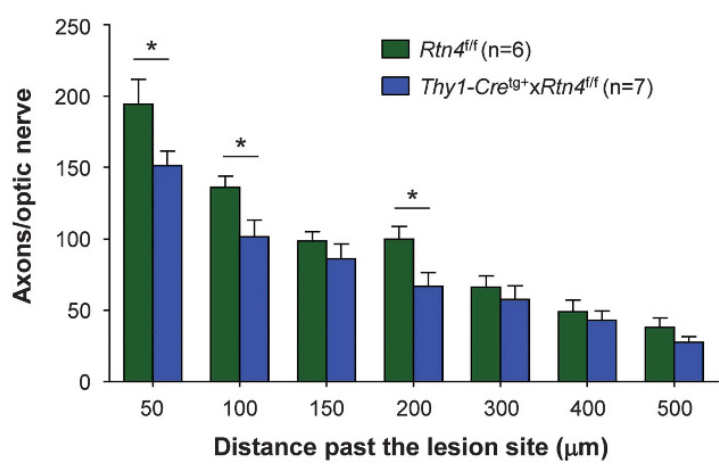

Figure 5 Axonal regeneration is reduced in neuron-specific Nogo-A KO animals. (a) To obtain a neuron-specific Nogo-A KO mouse line, mice expressing Cre-recombinase under the control of Thy 1 promoter ${ }^{42}$ were crossed with $R t n 4^{\text {floxflox }}$ mouse line. (b-d) Nogo-A and Nogo-B protein expression levels were studied by western

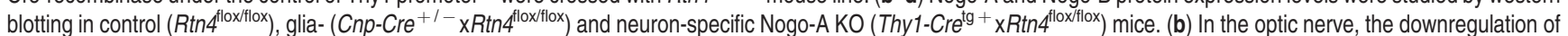
Nogo-A was more pronounced in glial $(\sim 80 \%)$ than in neuronal $(\sim 40 \%) \mathrm{KO}$, whereas Nogo-B was similarly upregulated in the two KO mouse lines. (c) In the primary motor cortex, the downregulation of Nogo-A was less pronounced in glial ( 40\%) than in neuronal ( $\sim 70 \%)$ KOs. Nogo-B was upregulated in the two KO mouse lines. (d) In the retina, Nogo-A expression was reduced by $\sim 90 \%$ in glial and by $\sim 40 \%$ in the neuron-specific KOs. Contrary to other tissues, the level of Nogo-B was not changed in the retina of the two conditional KO mouse lines. Statistics: one-way ANOVA, Bonferroni's Multiple Comparison Test, ${ }^{*} P<0.05,{ }^{* *} P<0.01,{ }^{* * *} P<0.001$. (e) The number of axonal fibers growing spontaneously through the lesion was statistically diminished in neuronal Nogo-A KO, Thy $1-C r e^{\operatorname{tg}+} \times R t^{\text {th }}{ }^{\text {floxfllox }}$ animals at 50,100 and $200 \mu \mathrm{m}$ past the injury site when compared with $R$ tn $4^{\text {floxflox }}$ control groups (mean \pm S.E.M., Student's $t$-test, ${ }^{*} P<0.05$ )

protein kinase blocking agents. ${ }^{43-45}$ The improved regeneration that we reported here for the optic nerve is in contrast with what has previously been observed in systemic, conventional $\mathrm{KO}$ mice. ${ }^{29}$ We speculate that the lack of axonal regeneration improvement observed after optic nerve crush in the conventional, full KO mouse line may be due, at least in part, to the lack of neuronal Nogo-A expression. ${ }^{29}$ Nogo-A levels are upregulated after injury in many RGCs, and the excision of Nogo-A gene by two different experimental approaches, the AAV2.Cre-mediated recombination and generation of a neuron-specific Nogo-A KO mouse line, decreased the retinal ganglion cell growth potential and prevented regeneration improvement in Cnp-Cre ${ }^{+/-}$ $\mathrm{x} R \operatorname{tn} 4^{\text {floxflox }} \mathrm{KOs}$. Taken together, our data show that targeted glial Nogo-A deletion appears to be the most effective way to stimulate axonal growth in the injured optic nerve.
The limitations of axonal regeneration by Nogo-A and guidance molecules in the injured optic nerve. Glial Nogo-A neutralization potentiated inflammation-induced axonal regeneration after ONC. The combined treatment effect emphasizes the importance of making the environment more permissive to boost regeneration upon intrinsic growth mechanism activation. The poor intrinsic neuronal growth can be improved by the deletion of phosphatase and tensin homolog and suppressor of cytokine signaling 3 (SOCS3), two key players for cell growth inhibition. ${ }^{46}$ Moreover, inflammation-inducing agents such as Zymosan or Pam3Cys ((S)-(2,3-bis(palmitoyloxy)-(2RS)-propyl)-Npalmitoyl-(R)-Cys-(S)-Ser(S)-Lys(4)-OH.trihydrochloride) have been shown to increase the intrinsic growth potential of adult neurons, thereby leading to enhanced regeneration. ${ }^{47,48}$ Acting at two levels, the neuronal growth program activation with Zymosan and the blockade of Nogo-A signaling potentiated 
a

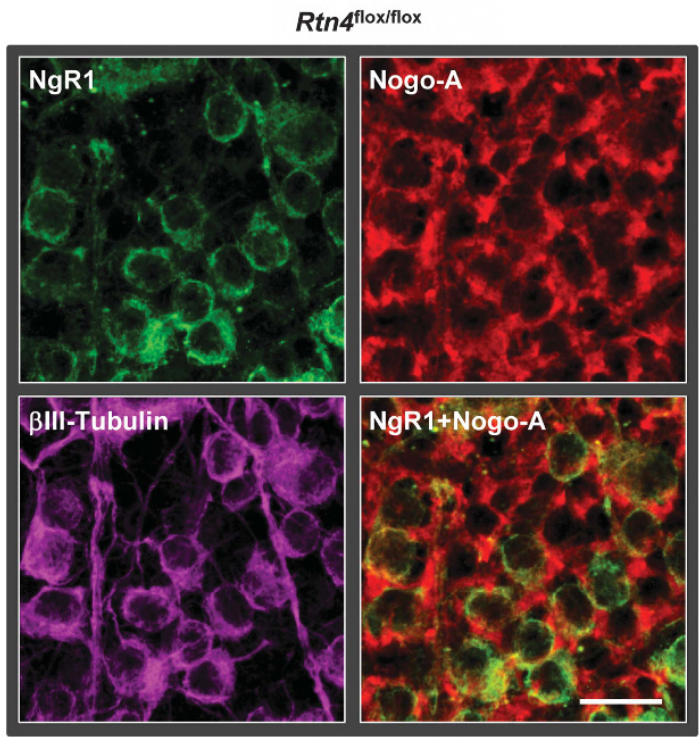

b

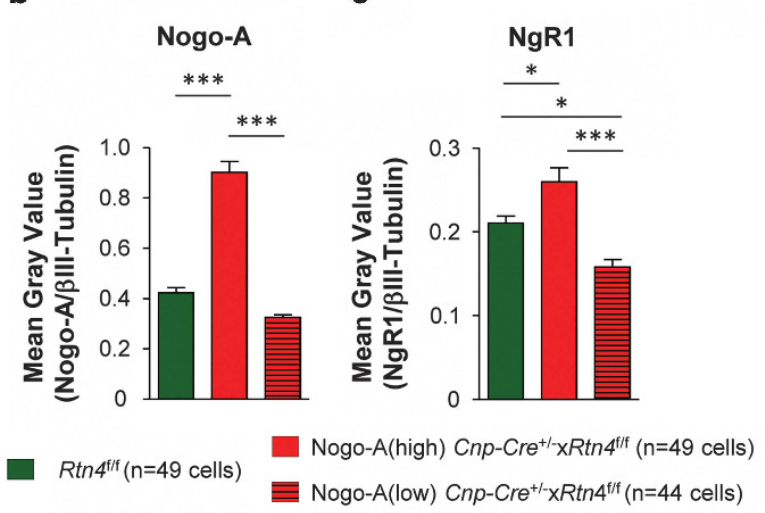

f

Neuron

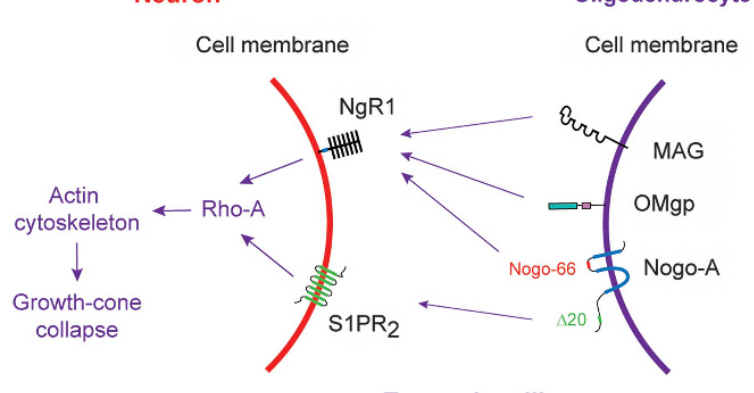

Trans-signalling
Cnp-Cre ${ }^{+/-} x \operatorname{Rtn}^{\text {flox/flox }}$

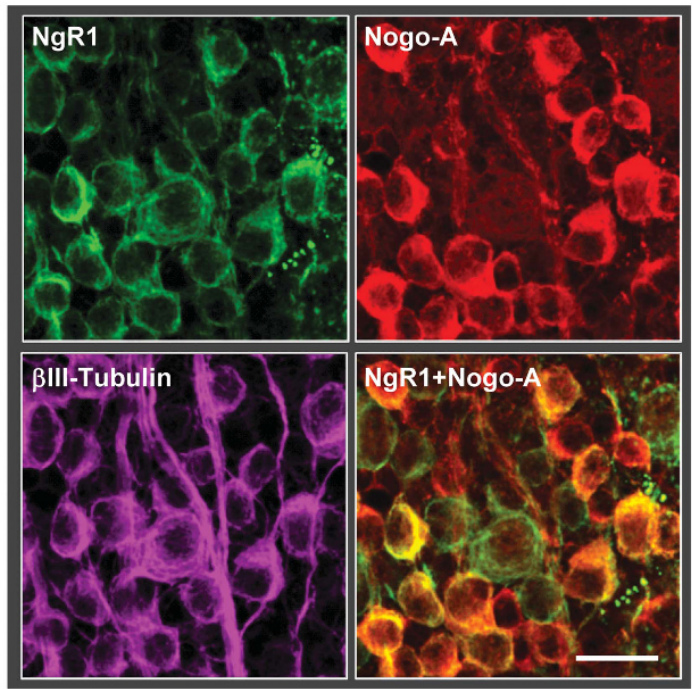

d

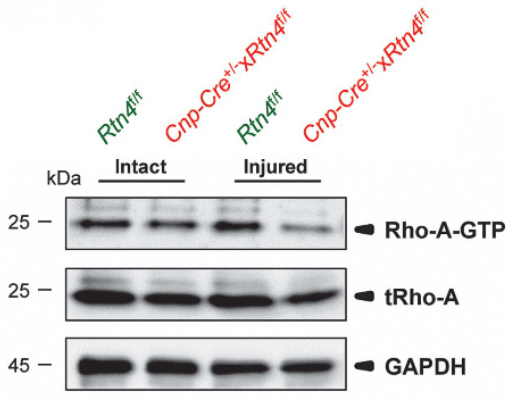

e

$R \operatorname{tn} 4^{\mathrm{f} / \mathrm{f}}(\mathrm{n}=5)$

Cnp-Cre ${ }^{+/} \times \operatorname{Rtn} 4^{f / f}(\mathrm{n}=5)$

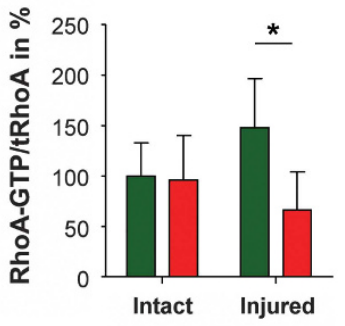

g

Neuron

Oligodendrocyte

Cell membrane

Cell membrane

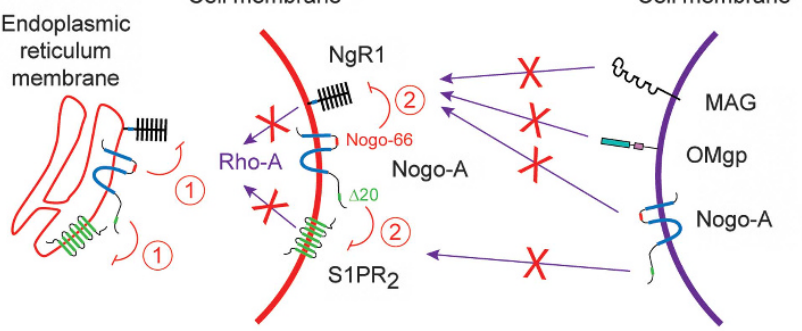

(1) Cis-sequestration

(2) Cis-hindrance

Figure 6 The correlation of Nogo-A and NgR1 expression levels in RGCs suggests a possible cis-interaction. (a) NgR1, Nogo-A and $\beta$ III-Tubulin were examined by

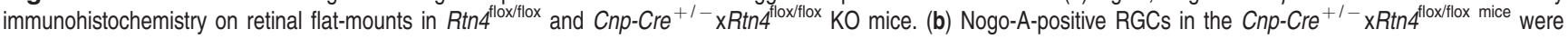
divided into high-(above the mean level of the control mice) and low-expressing cells. (c) The levels of NgR1 correlated with the Nogo-A levels in these two populations of intact RGCs. (d, e) Rho-A pull-down experiments revealed lower-activated Rho-A-GTP levels in the injured retinae of the Cnp-Cre ${ }^{+/-} \mathrm{xRtn}^{4} 4^{\text {loxfllox }} \mathrm{KO}$ mice. (f) Cartoon showing trans-activation of the NgR1-S1PR2/Rho-A signaling pathway by oligodendroglial Nogo-A. (g) Hypothetical cis-interaction between Nogo-A and its receptors in neurons, on the intracellular side, in the endoplasmic reticulum or at the cell membrane, leading to the downstream signaling blockade of Rho-A. Scale bar: (a) $=20 \mu \mathrm{m}$

regenerative growth. ${ }^{49-51}$ However, our data suggested that the range of axonal regeneration may be restricted by compensatory upregulation of EphA4 and EphrinA3 in glial cells. Further investigation are required to determine (1) how
Nogo-A gene ablation causes Ephrin expression increase, (2) if additional Ephrins and Semaphorins are upregulated as well and (3) if this mechanism can be neutralized to potentiate axonal regeneration in the damaged CNS. 
Our previous three-dimensional analyses revealed axonal guidance and patterning defects reflected by increased axonal U-turns and branching after growth induction in the injured optic nerve. $^{34,37}$ In the present study, we hypothesized that the myelin Nogo-A could have a role in axon guidance after optic nerve lesion. However, by examining individual growing axons in $3 \mathrm{D}$, we found no significant difference in the proportion of branching or U-turn-forming axons between mouse genotypes. The compensatory enhancement of EphrinA3 in the optic nerve and EphA4 in the retina that we detected in Cnp-Cre ${ }^{+1-}$ $x R t^{\text {floxflox }}$ KOs could influence the guidance of regenerating axons in a complex manner. For example, we reported that EphA4 KO mice were less prone to form branches in the injured optic nerve than WT animals. ${ }^{40}$ In Cnp-Cre ${ }^{+/-} \times R_{t n} 4^{\text {flox/flox }}$ $\mathrm{KOs}$, the lack of guidance and branching changes could result from the increase of EphA4 or EphrinA3 signaling in regenerating neurons. In future studies, the impact of compensatory myelin protein elevations and possibly of that of other repulsive molecules should be further addressed on axonal guidance in Cnp-Cre ${ }^{+/-} \mathrm{xRtn} 4^{\text {flox/flox }} \mathrm{KO}$ mice..$^{52,53}$

The role of Nogo-A in neuronal survival. We found that retinal ganglion cell survival was slightly, but significantly increased in the glial Nogo-A KO animals compared with control genotypes. Recently, several studies have suggested that neuronal Nogo-A might have a cell-autonomous role in improving neuronal survival under conditions of oxidative stress by scavenging reactive oxygen species, ${ }^{25}$ inhibiting oxidative damage ${ }^{26}$ or recruiting cytoprotective proteins. ${ }^{54}$ The moderate retinal ganglion cell survival observed in our study could be related to the neuronal Nogo-A upregulation in the glial Nogo-A KOs. Moreover, the activation of Rho-A by myelin Nogo-A could be damaging for neurons after injury; blocking Rho-A activation after spinal cord injury protected the cells from p75 ${ }^{\mathrm{NTR}}$-dependent apoptosis. ${ }^{55}$ Similarly, the increase of retinal ganglion cell survival in $\mathrm{Cnp}-\mathrm{Cre}^{+1-}$ $\mathrm{x} R \operatorname{tn} 4^{\text {floxflox }}$ mice could be due to the reduction of Rho-A activation that we observed in axotomized retinae.

Nogo-A and Nogo receptors in RGCs: trans- and cisinteraction? In our study, the increase of the NgR1immunohistochemical signal in the highly Nogo-A-positive RGCs of Cnp-Cre ${ }^{+/-} \times R \operatorname{tn} 4^{\text {flox/flox }} \mathrm{KOs}$ could reflect cisinteractions between the ligand and receptor. At the cell membrane, the sequestration and inactivation of ligands by cis-binding to adjacent receptors has previously been described to prevent trans-activation in the case of guidance molecules such as Ephrins, ${ }^{16}$ semaphorins ${ }^{17}$ or Slit-Robo, ${ }^{56}$ but also for the Notch signaling pathway. ${ }^{57}$ The co-expression of Nogo-A and NgR1 in RGCs of Cnp-Cre ${ }^{+/-} \times R_{t n} 4^{\text {flox/flox }}$ $\mathrm{KO}$ mice could prevent downstream activation of Rho-A after ONC and Nogo-A overexpression in F11 cells could partially counteract neurite outgrowth inhibition induced by Nogo-A- $\Delta 20$. These results suggest a cell-autonomous effect of neuronal Nogo-A on neurite outgrowth, potentially through cis-interaction with the Nogo receptors NgR1 or S1PR2.

In summary, the generation of cell type-specific $\mathrm{KO}$ mice allowed to observe that targeted deletion of Nogo-A from glial cells promotes more neuronal growth in the injured optic nerve than what has previously been reported in conventional $\mathrm{KO}$ animals. The inactivation of Nogo-A in glia appears as an optimized strategy to promote axonal regeneration in the CNS.

\begin{abstract}
Materials and Methods
Animals. Rtn $4^{\text {flox/flox }}$ mice were generated by TaconicArtemis (Cologne, Germany). Briefly, the conditional Rtn4 exon 3 allele was generated by homologous recombination in C57BL/6N ES cells. Exon 3 was flanked by LoxP sites using a targeting vector with $7.2 \mathrm{~kb}$ (long arm) and $3.2 \mathrm{~kb}$ (short arm) homologous sequences, respectively. Correct targeting was verified in ES cells using southern blotting before performing blastocyst injections. Highly chimeric male offsprings were bred with $\mathrm{C} 57 \mathrm{BL} / 6$ females, transgenic for the presence of a recombinase gene (Flp-Deleter line). Germline transmission was identified by the presence of a black coat color, strain C57BL/6. Flp-mediated removal of the FRT site-flanked positive selection marker gene (PuroR) was verified in the next generation. Cre-mediated excision of exon 3 resulted in specific loss of function of the Rtn4 isoform A (Nogo-A), whereas the Rtn4 isoforms B and C (Nogo-B and Nogo-C) were still expressed. Glia and neuron-specific Nogo-A KO mice were generated to study the role of glial versus neuronal Nogo-A on axonal regeneration. Rtn $4^{\text {floxfllox }}$ mice were crossed with mice expressing Crerecombinase under the control of the $2^{\prime}, 3^{\prime}$-cyclic nucleotide phosphodiesterase (Cnp) or Thy1 promoter, respectively. The Cnp-Cre line was generated in the laboratory of Klaus-Armin Nave. ${ }^{30}$ The Thy1-Cre line was obtained from the Jackson Laboratory (Bar Harbor, ME, USA) (FVB/N-Tg(Thy1-cre)1VIn/J) and back-crossed with $\mathrm{C} 57 \mathrm{BL} / 6$ background more than eight times before the breeding was started with Rtn $4^{\text {floxfllox }}$ animals. All procedures and surgeries were performed on 2-4 month old mice of mixed genders and different genotypes. Animal experiments were performed in accordance with the guidelines of the Veterinary Office of the Canton of Zurich.
\end{abstract}

AAV vector production and application. An AAV2.Cre-mCherry expressing virus was generated to selectively infect RGCs. AAV vectors were produced by standard methods. To selectively excise Nogo-A from retinal ganglion cell neurons in the retina, the AAV2.Cre-mCherry virus was injected to mice with $R \operatorname{tn} 4^{\text {floxfllox }}$ genotype. $1.5 \mu \mathrm{l}$ of AAV2.Cre-mCherry virus $\left(10^{14} \mathrm{vg} / \mathrm{ml}\right)$ was administered intraocularly using a $10 \mu$ l Hamilton syringe adapted with a pulledglass tip. To allow the diffusion of the virus, the needle was kept in place for 3-4 min and then carefully removed. Attention was paid not to damage the lens during the injections. To allow time for optimal transgene expression in vivo, the injections were performed 4 weeks before the optic nerve crush (ONC) injury.

Axonal regeneration analysis on longitudinal optic nerve sections. We performed ONC injuries to study axonal regeneration in the optic nerve and neuronal survival in the retina. The optic nerve was exposed intraorbitally and then crushed by tying a knot with a $9-0$ suture at $\sim 0.5 \mathrm{~mm}$ from the back of the eye. The suture was carefully removed and the integrity of the ophthalmic artery was examined by fundus examination. To induce intraocular inflammation, $2 \mu \mathrm{l}$ of $1 \%$ Zymosan dissolved in phosphate-buffered saline (PBS) was injected intraocularly at the time of the injury. Thirteen days after ONC, the optic axons were anterogradely traced by intraocularly injecting $1.5 \mu \mathrm{l}$ of $0.5 \%$ cholera toxin B conjugated to Alexa594 (CTB-A594, Molecular Probes, Zug, Switzerland). On the following day, the animals were perfused with $4 \%$ paraformaldehyde (PFA) and the optic nerves were processed as described below. CTB-A594-positive axons were observed on longitudinal optic nerve sections $(14 \mu \mathrm{m})$ with a Zeiss Axioskop 2 Plus microscope (Carl Zeiss, Feldbach, Switzerland) and images were taken with a CCD video camera at $\times 20$ magnification. The number of growing axons was estimated at different distances $(50,100,150,200,300,400$, and 500 to $1000 \mu \mathrm{m})$ after the lesion site. Five-six optic nerve sections were analyzed per animal. An estimation of the number of axons per optic nerve $(\Sigma)$ was calculated with the following formula: $\Sigma_{d}=\Pi \times$ $R^{2} \times$ (average number of axons $\left./ \mathrm{mm}\right) / T$. The sum $(\Sigma)$ of axons at a given distance (d) was obtained using the average optic nerve radius (R) of all optic nerves at $500 \mu \mathrm{m}$ past the lesion site, and a thickness (T) of the tissue slices of $14 \mu \mathrm{m}$. For statistical analysis with multiple comparisons, ANOVA test was applied followed by a Bonferroni's post hoc test. Animals with retinal haemorrhages or ischemia were excluded from the analysis.

Optic nerve preparation and clearing for 3D analysis of regenerating axons. To visualize CTB-A594-labeled axons in the whole 
injured optic nerve, the tissue was cleared following the adapted protocol from. ${ }^{37}$ After intracardial perfusion with PBS and $4 \%$ PFA, optic nerves were further fixed overnight, then rinsed with PBS and stored at $4{ }^{\circ} \mathrm{C}$. The samples were dehydrated in baths of increasing concentrations of tetrahydrofuran (THF, Sigma-Aldrich, Buchs, Switzerland) $(50,80$, and $100 \%)$ for $30 \mathrm{~min}$ each and for additional $30 \mathrm{~min}$ in $100 \%$ THF at room temperature under constant agitation. To remove traces of water, the optic nerves were placed in dichloromethane for $3-4 \mathrm{~h}$ at room temperature. In the BABB clearing solution (mixture of benzyl alcohol and benzylbenzoate (1:2, Sigma-Aldrich)) the white optic nerve turned transparent within $30 \mathrm{~s}$. The whole optic nerves were mounted in the clearing medium before imaging. Image stacks were taken using an inverted confocal Leica SP5 microscope (Leica Microsystems, Mannheim, Germany) equipped with a x63 glycerin immersion objective (NA: 1.3). This setup was used to scan axons throughout the whole thickness of the optic nerve. To obtain 3D reconstruction of the optic nerves, image stacks were stitched using the XuvTools42 software ${ }^{58}$ and the resulting macro-stack was exported to the Imaris Software (Bitplane, Zurich, Switzerland) to create 3D projections. Individual axons were analyzed semi-automatically with the Filament Tracers' advanced manual tracing mode ('AutoDepth'). The percentage of U-turns and branching was calculated between 100 and $300 \mu \mathrm{m}$ past the lesion site. The best traced 30-60 fibers were selected for growth pattern analysis.

Neuronal survival analysis. Retinal ganglion cell survival was examined 2 weeks after ONC injury. The animals were intracardially perfused with 4\% PFA and the injured and intact retinae were flat-mounted. RGCs were visualized by immunostaining for $\beta$ III-Tubulin (1: 1000, Promega, Madison, WI, USA), a specific and reliable marker for labelling all RGCs. The antibodies were diluted in blocking solution $(0.3 \%$ Triton-X- $100,5 \%$ of normal serum and $0.05 \%$ sodium azide in PBS), and the retinae were incubated at $4{ }^{\circ} \mathrm{C}$ with primary and secondary antibodies, for 5 and 3 days, respectively. The $\beta I I I$-Tubulin-positive RGCs were imaged in the four quadrants of the retina using a Leica SPE-II confocal microscope equipped with a $x 40$ oil immersion objective (NA 1.25). Image stacks were acquired in the ganglion cell layer with a step size of $0.5 \mu \mathrm{m}$ and a resolution of $1024 \times 1024$ pixels $(0.275 \mu \mathrm{m} /$ pixel $)$. The number of retinal ganglion cell bodies was quantified in grids of $62500 \mu \mathrm{m}^{2}$ at 1 and $1.5 \mathrm{~mm}$ distances from the optic disc. The density of surviving RGCs was calculated per $\mathrm{mm}^{2}$.

Retina and optic nerve processing and immunostaining. Mice were killed by injecting an overdose of anaesthetics intraperitoneally and perfused intracardially with PBS and 4\% PFA. Optic nerves and eyes were dissected, the latter by removing the cornea and the lens from the eyecup. For retinal cross sections and longitudinal optic nerve sections, the eye cups and optic nerves were post-fixed in $4 \%$ PFA overnight at $4{ }^{\circ} \mathrm{C}$. The tissues were then cryoprotected in $30 \%$ sucrose and frozen in OCT compound (Tissue-TEK, Sakura, Torrance, CA, USA) with a 2-methylbutane bath cooled with liquid nitrogen. Optic nerves and retinal sections were cut $(14 \mu \mathrm{m})$ with a cryostat. Immunohistochemical stainings were performed in a blocking solution (5\% of normal goat serum or $5 \%$ BSA, $0.3 \%$ Triton- $X-100$ and $0.05 \%$ sodium azide in PBS). Primary antibodies were applied overnight at $4{ }^{\circ} \mathrm{C}$ and after PBS washes, sections were incubated with the appropriate secondary antibody for $1 \mathrm{~h}$ at room temperature. The slides were mounted in Mowiol solution (10\% Mowiol 4-88, Calbiochem, Cambridge, UK, in $100 \mathrm{mM}$ Tris, $\mathrm{pH} 8.5,25 \%$ glycerol and $0.1 \%$ DABCO). Primary antibodies were: rabbit anti-Nogo-A (Laura, Rb173A40) serum $(1: 200)$, mouse anti-glutamine synthetase $(1: 300$, Chemicon, Zug, Switzerland), rabbit anti-CRALBP $(1: 1000$, kindly provided by Prof. JC Saari, Washington), mouse anti-APC (1:300, Chemicon), mouse anti-CNP $(1: 300$, Chemicon), goat anti-NgR1 (1:50, R\&D Systems, Minneapolis, MN, USA), rabbit anti-phospho-ERK1/2 (1:100, Cell Signaling, Danvers, MA, USA), rabbit anti-phospho-CREB (1:100, Cell Signaling), rabbit anti-phospho-Cofilin (1:200, Abcam, Cambridge, UK) and mouse anti- $\beta$ III-Tubulin (1:1000, Promega). Immunofluorescent labelling was analyzed with a Zeiss Axioskop 2 Plus microscope or with Leica SPE-II confocal microscope.

Western blot analysis. After cervical dislocation, retinae and optic nerves were quickly dissected out and flash frozen in liquid nitrogen. Tissues were kept at $-80{ }^{\circ} \mathrm{C}$ until extraction in lysis buffer (RIPA buffer: $150 \mathrm{mM} \mathrm{NaCl}, 1 \% \mathrm{NP} 40$, $0,5 \%$ deoxycholate, $0.1 \%$ SDS in $50 \mathrm{mM}$ Tris buffer at $\mathrm{pH} 8$ ) containing protease inhibitors (Complete mini, Roche Diagnostics, Indianapolis, IN, USA). Samples were fully homogenized and let on ice for $60 \mathrm{~min}$. After centrifugation for $15 \mathrm{~min}$ at
$15000 \times g, \quad 4^{\circ} \mathrm{C}$, supernatants were collected and processed for protein concentration analysis (Bio-Rad Laboratories, Richmond, CA, USA, RC DC Protein Assay). Retinal and optic nerve proteins ( $20 \mu \mathrm{g} / \mathrm{lane}$ ) were separated by electrophoresis on a $4-12 \%$ polyacrylamide gel and transferred to nitrocellulose membranes. Blots were incubated in a blocking solution of either $2 \%$ Top Block (Lubio Science, Luzern, Switzerland) or $5 \%$ BSA (bovine serum albumin) in $0.2 \%$ TBST $(0.2 \%$ Tween-20 in Tris-base $0.1 \mathrm{M}, \mathrm{pH} 7.4)$ for $1 \mathrm{~h}$ at room temperature, then incubated with primary antibodies overnight at $4{ }^{\circ} \mathrm{C}$. Following the washing steps, membranes were incubated with horseradish peroxidase-conjugated antimouse or anti-rabbit secondary antibodies (1:10000-1:25 000; Pierce Biotechnology, Rockford, IL, USA). Primary antibodies were rabbit anti-Nogo-A/B (Bianca, $\mathrm{Rb} 140)$ serum (1:20000), mouse anti-L-MAG serum (1:1000, polyclonal), ${ }^{59}$ mouse anti-EphA4 (1:200, Invitrogen, Zug, Switzerland), rabbit anti-EphrinA3 (1:200, Invitrogen), mouse anti-S1PR2 (1:500, Santa Cruz Biotechnology, Santa Cruz, CA, USA), rabbit anti-phospho-STAT3 (1:500, Cell Signaling), rabbit anti-STAT3 $(1: 500$, Cell Signaling), rabbit anti-phospho-ERK1/2 $(1: 1000$, Cell Signaling), rabbit anti-ERK1/2 (1:1000, Cell Signaling), rabbit anti-phospho-AKT (1:500, Cell Signaling), rabbit anti-AKT (1:500, Cell Signaling), rabbit anti-phospho-CREB $(1: 500$, Cell Signaling), rabbit anti-CREB $(1: 500$, Cell Signaling), rabbit anti-phospho-Cofilin (1:500, Abcam), rabbit anti-Cofilin (1:500, Cell Signaling), and mouse anti-glyceraldehyde 3-phosphate dehydrogenase (GAPDH) (1:20000; Abcam). Protein bands were detected with SuperSignal West Pico Chemiluminescent Substrate (Pierce Biotechnology) in a Stella detector (Raytest, Straubenhardt, Germany). Band intensities were measured with the Image $\mathrm{J}$ software (NIH).

Rho-A pull-down. After rapid dissection of intact and injured (3 days post operation) retinae in TBS, the samples were flash frozen in liquid nitrogen and stored at $-80^{\circ} \mathrm{C}$ until performing the Rho-A pull-down. The pull-down of activated RhoA-GTP was subsequently performed using the RhoA Activation Assay Biochem Kit according to the manufacturer's instructions (Cytoskeleton, Inc., Denver, CO, USA) combined with a previously described protocol. ${ }^{60}$ The Rho-A-GTP pull-down and total lysate samples were then subjected to electrophoresis on a $4-12 \%$ polyacrylamide gel and transferred to nitrocellulose membranes. After blocking with $5 \%$ BSA in $0.2 \%$ TBST for $1 \mathrm{~h}$, the membranes were incubated overnight at $4{ }^{\circ} \mathrm{C}$ with a rabbit anti-Rho-A $(1: 400$, Cell Signaling) primary antibody. The secondary antibody incubation and signal detection was performed as described before for the western blots.

Semi-quantitative RT-PCR (qRT-PCR). After cervical dislocation, intact and injured whole retinae were rapidly dissected in PBS. The samples were flash frozen in liquid nitrogen and stored at $-80^{\circ} \mathrm{C}$ until RNA extraction. The retinal RNA was prepared using the RNeasy RNA isolation kit (Qiagen, Hombrechtikon, Switzerland), including a DNase treatment to digest the residual genomic DNA. For reverse transcription, equal amounts of total RNA were transformed to CDNA by using oligo(dT) primers and M-MLV reverse transcriptase (Promega). $10 \mathrm{ng}$ of cDNA was amplified in the Light Cycler 480 thermocycler (Roche Diagnostics AG) with the polymerase ready mix (SYBR Green I Master; Roche Diagnostics). The following specific primers were designed to span intronic sequences or cover exon-intron boundaries: Gapdh (forward, 5'-CAGCAATGCATCCTGCACC-3'; reverse, 5'-TGGACTGTGGTCATGAGCCC-3'), Cnp (forward, 5'-AGGAGAAG CTTGAGCTGGTC-3'; reverse, 5'-CGATCTCTTCACCACCTCCT-3'), Nogo-A/ Rtn4 (forward, 5'-CAGTGGATGAGACCCTTTTTG-3'; reverse, 5'-GCTGCTC CTTCAAATCCATAA-3'), NgR1/Rtn4R (forward, 5'-CTCGACCCCGAAGAT GAAG-3'; reverse: 5'-TGTAGCACACACAAGCACCAG-3'), Gap-43 (forward, 5'-T GCTGTCACTGATGCTGCT-3'; reverse, 5'-GGCTTCGTCTACAGCGTCTT-3'), small proline-rich protein $1 \mathrm{~A}$ (Sprr1A, forward, $5^{\prime}$-GAACCTGCTCTTCTCTGAGT$3^{\prime}$; reverse, 5'-AGCTGAGGAGGTACAGTG-3'). For relative quantification of gene expression, mRNA levels were normalized to GAPDH using the comparative threshold cycle $\left(\Delta \Delta^{\mathrm{CT}}\right)$ method and a control sample was used to calculate the relative values. Each reaction was done in triplicate and 3-4 mice per condition were analyzed.

Cell cultures. The effects of AAV2.green fluorescent protein (GFP) and AAV2.Nogo-A on neurite outgrowth were evaluated in vitro by infecting F11 cells. The F11 cell line, kindly provided by Prof. RE van Kesteren (Amsterdam, The Netherlands), was maintained as described before. ${ }^{61} \mathrm{~F} 11$ cells were plated at a density of 100000 cells per well in six-well plates and were treated with AAV2.GFP or AAV2.Nogo-A viruses $24 \mathrm{~h}$ later. After a period of 4 days after 
infection, F11 cells were transferred to 4-well dishes at a density of 2000 cells per well. The four-well dishes were coated by different concentrations of Nogo-A- $\Delta 20$ substrate $\left(0,0.5,1\right.$ and $\left.2.5 \mu \mathrm{g} / \mathrm{cm}^{2}\right)$ diluted in PBS at $4{ }^{\circ} \mathrm{C}$ for $12 \mathrm{~h}$. Twenty four hours after plating the cells on Nogo-A- $\Delta 20$ substrate, F11 cells were differentiated by adding $10 \mu \mathrm{M}$ of Forskolin (Sigma-Aldrich) for $48 \mathrm{~h}$. To visualize neurite extension, $\mathrm{F} 11$ cells were stained with $\beta$ III-Tubulin antibody. Measurement of neurite length was carried out using the Neuron $\mathrm{J}$ plugin in the Image $\mathrm{J}$ software (NIH). The mean of the total neurite length was calculated for the $A A V 2 . G F P$ and AAV2.Nogo-A treatments on all four Nogo-A- $\Delta 20$ substrate concentrations measuring between 80 and 110 cells.

\section{Conflict of Interest}

The authors declare no conflict of interest.

Acknowledgements. This work was supported by the Swiss National Science Foundation (SNF grant \#31003A-149315-1 for MES), the European Research Council (ERC, 'Nogorise' \#294115 for MES) and by the International Foundation for Research in Paraplegia (IRP, P115 for BT). We thank Professor Klaus-Armin Nave for kindly providing the Cnp-Cre mouse line, Professor Ronald van Kesteren for sending us the F11 cells and Professor Schaeren-Wiemers for sharing the L-MAG antiserum with us. We also thank A Guzik-Kornacka for help with tissue dissections and protein/mRNA extractions.

1. Yiu G, He Z. Glial inhibition of CNS axon regeneration. Nat Rev Neurosci 2006; 7: 617-627.

2. Schwab ME. Functions of Nogo proteins and their receptors in the nervous system. Nat Rev Neurosci 2010; 11: 799-811.

3. Goldberg JL, Espinosa JS, Xu Y, Davidson N, Kovacs GT, Barres BA. Retinal ganglion cells do not extend axons by default: promotion by neurotrophic signaling and electrical activity. Neuron 2002; 33: 689-702.

4. Schwab ME. Nogo and axon regeneration. Curr Opin Neurobiol 2004; 14: 118-124.

5. Pernet V, Schwab ME. The role of Nogo-A in axonal plasticity, regrowth and repair. Cell Tissue Res 2012; 349: 97-104.

6. Bareyre FM, Haudenschild B, Schwab ME. Long-lasting sprouting and gene expression changes induced by the monoclonal antibody $\mathrm{IN}-1$ in the adult spinal cord. J Neurosci 2002; 22: 7097-7110.

7. Simonen M, Pedersen V, Weinmann O, Schnell L, Buss A, Ledermann B et al. Systemic deletion of the myelin-associated outgrowth inhibitor Nogo-A improves regenerative and plastic responses after spinal cord injury. Neuron 2003; 38: 201-211.

8. Thallmair M, Metz GA, Z'Graggen WJ, Raineteau O, Kartje GL, Schwab ME. Neurite growth inhibitors restrict plasticity and functional recovery following corticospinal tract lesions. Nat Neurosci 1998; 1: 124-131.

9. Dimou L, Schnell L, Montani L, Duncan C, Simonen M, Schneider R et al. Nogo-A-deficient mice reveal strain-dependent differences in axonal regeneration. $J$ Neurosci 2006; 26 : 5591-5603.

10. Kim JE, Li S, GrandPre T, Qiu D, Strittmatter SM. Axon regeneration in young adult mice lacking Nogo-A/B. Neuron 2003; 38: 187-199.

11. Schwab ME, Strittmatter SM. Nogo limits neural plasticity and recovery from injury. Curr Opin Neurobiol 2014; 27C: 53-60.

12. Huber AB, Weinmann O, Brosamle C, Oertle T, Schwab ME. Patterns of Nogo mRNA and protein expression in the developing and adult rat and after CNS lesions. J Neurosci 2002; 22: 3553-3567.

13. Wang X, Chun SJ, Treloar H, Vartanian T, Greer CA, Strittmatter SM. Localization of Nogo-A and Nogo-66 receptor proteins at sites of axon-myelin and synaptic contact. J Neurosci 2002; 22: 5505-5515.

14. Fournier AE, GrandPre T, Strittmatter SM. Identification of a receptor mediating Nogo-66 inhibition of axonal regeneration. Nature 2001; 409: 341-346.

15. Kempf A, Tews B, Arzt ME, Weinmann O, Obermair FJ, Pernet $V$ et al. The sphingolipid receptor S1PR2 is a receptor for Nogo-a repressing synaptic plasticity. PLOS Biol 2014; 12: e1001763.

16. Egea J, Klein R. Bidirectional Eph-ephrin signaling during axon guidance. Trends Cell Biol 2007; 17: 230-238.

17. Haklai-Topper L, Mlechkovich G, Savariego D, Gokhman I, Yaron A. Cis interaction between Semaphorin6A and Plexin-A4 modulates the repulsive response to Sema6A. EMBO J 2010; 29: 2635-2645.

18. Delekate A, Zagrebelsky M, Kramer S, Schwab ME, Korte M. NogoA restricts synaptic plasticity in the adult hippocampus on a fast time scale. Proc Natl Acad Sci USA 2011; 108: 2569-2574.

19. Tews B, Schonig K, Arzt ME, Clementi S, Rioult-Pedotti MS, Zemmar A et al. Synthetic microRNA-mediated downregulation of Nogo-A in transgenic rats reveals its role as regulator of synaptic plasticity and cognitive function. Proc Natl Acad Sci USA 2013; 110: 6583-6588.

20. Wills ZP, Mandel-Brehm C, Mardinly AR, McCord AE, Giger RJ, Greenberg ME. The nogo receptor family restricts synapse number in the developing hippocampus. Neuron 2012; 73: $466-481$.

21. Raiker SJ, Lee H, Baldwin KT, Duan Y, Shrager P, Giger RJ. Oligodendrocyte-myelin glycoprotein and Nogo negatively regulate activity-dependent synaptic plasticity. J Neurosci 2010; 30: 12432-12445.

22. Akbik FV, Bhagat SM, Patel PR, Cafferty WB, Strittmatter SM. Anatomical plasticity of adult brain is titrated by Nogo Receptor 1. Neuron 2013; 77: 859-866.

23. Mathis C, Schroter A, Thallmair M, Schwab ME. Nogo-a regulates neural precursor migration in the embryonic mouse cortex. Cereb Cortex 2010; 20: 2380-2390.

24. Mingorance-Le Meur A, Zheng B, Soriano E, del Rio JA. Involvement of the myelinassociated inhibitor Nogo-A in early cortical development and neuronal maturation. Cereb Cortex 2007; 17: 2375-2386.

25. Mi YJ, Hou B, Liao QM, Ma Y, Luo Q, Dai YK et al. Amino-Nogo-A antagonizes reactive oxygen species generation and protects immature primary cortical neurons from oxidative toxicity. Cell Death Differ 2012; 19: 1175-1186.

26. Guo F, Jin WL, Li LY, Song WY, Wang HW, Gou XC et al. M9, a novel region of aminoNogo-A, attenuates cerebral ischemic injury by inhibiting NADPH oxidase-derived superoxide production in mice. CNS Neurosci Ther 2013; 19: 319-328.

27. Oertle T, van der Haar ME, Bandtlow CE, Robeva A, Burfeind P, Buss A et al. Nogo-A inhibits neurite outgrowth and cell spreading with three discrete regions. J Neurosci 2003; 23: 5393-5406.

28. Petrinovic MM, Duncan CS, Bourikas D, Weinman O, Montani L, Schroeter A et al. Neuronal Nogo-A regulates neurite fasciculation, branching and extension in the developing nervous system. Development 2010; 137: 2539-2550.

29. Pernet V, Joly S, Dalkara D, Schwarz O, Christ F, Schaffer D et al. Neuronal Nogo-A upregulation does not contribute to ER stress-associated apoptosis but participates in the regenerative response in the axotomized adult retina. Cell Death Differ 2011; 19: 1096-1108.

30. Lappe-Siefke C, Goebbels S, Gravel M, Nicksch E, Lee J, Braun PE et al. Disruption of Cnp1 uncouples oligodendroglial functions in axonal support and myelination. Nat Genet 2003; 33: 366-374.

31. Sprinkle TJ. 2',3'-cyclic nucleotide 3'-phosphodiesterase, an oligodendrocyte-Schwann cell and myelin-associated enzyme of the nervous system. Crit Rev Neurobiol 1989; 4: 235-301.

32. Aigner L, Arber S, Kapfhammer JP, Laux T, Schneider C, Botteri F et al. Overexpression of the neural growth-associated protein GAP-43 induces nerve sprouting in the adult nervous system of transgenic mice. Cell 1995; 83: 269-278.

33. Bonilla IE, Tanabe K, Strittmatter SM. Small proline-rich repeat protein $1 \mathrm{~A}$ is expressed by axotomized neurons and promotes axonal outgrowth. J Neurosci 2002; 22: 1303-1315.

34. Pernet V, Joly S, Jordi N, Dalkara D, Guzik-Kornacka A, Flannery JG et al. Misguidance and modulation of axonal regeneration by Stat3 and Rho/ROCK signaling in the transparent optic nerve. Cell Death Dis 2013; 4: e734.

35. Yin $Y$, Cui $Q$, Gilbert HY, Yang Y, Yang Z, Berlinicke $C$ et al. Oncomodulin links inflammation to optic nerve regeneration. Proc Natl Acad Sci USA 2009; 106: 19587-19592.

36. Yin Y, Henzl MT, Lorber B, Nakazawa T, Thomas TT, Jiang F et al. Oncomodulin is a macrophage-derived signal for axon regeneration in retinal ganglion cells. Nat Neurosci 2006; 9: 843-852.

37. Luo X, Salgueiro Y, Beckerman SR, Lemmon VP, Tsoulfas P, Park KK. Three-dimensional evaluation of retinal ganglion cell axon regeneration and pathfinding in whole mouse tissue after injury. Exp Neurol 2013; 247: 653-662.

38. Dodt HU, Leischner U, Schierloh A, Jahrling N, Mauch CP, Deininger K et al. Ultramicroscopy: three-dimensional visualization of neuronal networks in the whole mouse brain. Nat Methods 2007; 4: 331-336.

39. Kempf A, Montani L, Petrinovic MM, Schroeter A, Weinmann O, Patrignani A et al. Upregulation of axon guidance molecules in the adult central nervous system of Nogo-A knockout mice restricts neuronal growth and regeneration. Eur J Neurosci 2013; 38: 3567-3579.

40. Joly S, Jordi N, Schwab ME, Pernet V. The Ephrin receptor EphA4 restricts axonal sprouting and enhances branching in the injured mouse optic nerve. Eur J Neurosci 2014; e-pub ahead of print 12 July 2014; doi:10.1111/ejn.12677.

41. Cafferty WB, Duffy P, Huebner E, Strittmatter SM. MAG and OMgp synergize with Nogo-A to restrict axonal growth and neurological recovery after spinal cord trauma. $J$ Neurosci 2010; 30: 6825-6837.

42. Moore DL, Blackmore MG, Hu Y, Kaestner KH, Bixby JL, Lemmon VP et al. KLF family members regulate intrinsic axon regeneration ability. Science 2009; 326 : 298-301.

43. Liebscher T, Schnell L, Schnell D, Scholl J, Schneider R, Gullo M et al. Nogo-A antibody improves regeneration and locomotion of spinal cord-injured rats. Ann Neurol 2005; 58: 706-719.

44. Li S, Liu BP, Budel S, Li M, Ji B, Walus L et al. Blockade of Nogo-66, myelin-associated glycoprotein, and oligodendrocyte myelin glycoprotein by soluble Nogo-66 receptor 
promotes axonal sprouting and recovery after spinal injury. J Neurosci 2004; 24 10511-10520.

45. Dergham P, Ellezam B, Essagian C, Avedissian H, Lubell WD, McKerracher L. Rho signaling pathway targeted to promote spinal cord repair. J Neurosci 2002; 22 : 6570-6577.

46. Sun F, Park KK, Belin S, Wang D, Lu T, Chen G et al. Sustained axon regeneration induced by co-deletion of PTEN and SOCS3. Nature 2011; 480: 372-375.

47. Yin Y, Cui Q, Li Y, Irwin N, Fischer D, Harvey AR et al. Macrophage-derived factors stimulate optic nerve regeneration. J Neurosci 2003; 23: 2284-2293.

48. Hauk TG, Leibinger M, Muller A, Andreadaki A, Knippschild U, Fischer D. Stimulation of axon regeneration in the mature optic nerve by intravitreal application of the toll-like receptor 2 agonist Pam3Cys. Invest Ophthalmol Vis Sci 2010; 51: 459-464.

49. Wang X, Hasan O, Arzeno A, Benowitz LI, Cafferty WB, Strittmatter SM. Axonal regeneration induced by blockade of glial inhibitors coupled with activation of intrinsic neuronal growth pathways. Exp Neurol 2012; 237: 55-69.

50. Fischer D, He Z, Benowitz LI. Counteracting the Nogo receptor enhances optic nerve regeneration if retinal ganglion cells are in an active growth state. $J$ Neurosci 2004; 24 : 1646-1651.

51. Dickendesher TL, Baldwin KT, Mironova YA, Koriyama Y, Raiker SJ, Askew KL et al. $\mathrm{NgR} 1$ and NgR3 are receptors for chondroitin sulfate proteoglycans. Nat Neurosci 2012; 15: $703-712$.

52. Giger RJ, Hollis 2nd ER, Tuszynski MH. Guidance molecules in axon regeneration. Cold Spring Harb Perspect Biol 2010; 2: a001867.
53. Pernet V, Schwab ME. Lost in the jungle: new hurdles for optic nerve axon regeneration. Trends Neurosci 2014; 37: 381-387.

54. Kern F, Stanika RI, Sarg B, Offterdinger M, Hess D, Obermair GJ et al. Nogo-A couples with Apg-1 through interaction and co-ordinate expression under hypoxic and oxidative stress. Biochem J 2013; 455: 217-227.

55. Dubreuil $\mathrm{Cl}$, Winton MJ, McKerracher $\mathrm{L}$. Rho activation patterns after spinal cord injury and the role of activated Rho in apoptosis in the central nervous system. J Cell Biol 2003; 162 : 233-243.

56. Jaworski A, Tessier-Lavigne M. Autocrine/juxtaparacrine regulation of axon fasciculation by Slit-Robo signaling. Nat Neurosci 2012; 15: 367-369.

57. Sprinzak D, Lakhanpal A, Lebon L, Santat LA, Fontes ME, Anderson GA et al. Cis-interactions between Notch and Delta generate mutually exclusive signalling states. Nature 2010; 465: 86-90.

58. Emmenlauer M, Ronneberger O, Ponti A, Schwarb P, Griffa A, Filippi A et al. XuvTools: free, fast and reliable stitching of large 3D datasets. J Microsc 2009; 233: 42-60.

59. Erb M, Steck AJ, Nave KA, Schaeren-Wiemers N. Differential expression of L- and S-MAG upon cAMP stimulated differentiation in oligodendroglial cells. J Neurosci Res 2003; 71: 326-337.

60. Pellegrin S, Mellor H. Rho GTPase activation assays. Curr Protoc Cell Biol 2008; chapter 14: Unit 14, 18; doi:10.1002/0471143030.cb1408s38.

61. MacGillavry HD, Stam FJ, Sassen MM, Kegel L, Hendriks WT, Verhaagen J et al. NFIL3 and CAMP response element-binding protein form a transcriptional feedforward loop that controls neuronal regeneration-associated gene expression. J Neurosci 2009; 29: 15542-15550

Supplementary Information accompanies this paper on Cell Death and Differentiation website (http://www.nature.com/cdd) 